\title{
A Strategic Location Decision-Making Approach for Multi-Tier Supply Chain Sustainability
}

\author{
Petchprakai Sirilertsuwan ${ }^{1,2,3,4, * \mathbb{C}}$, Sébastien Thomassey ${ }^{2}$ and Xianyi Zeng ${ }^{2}$ \\ 1 GEMTEX Laboratory, The ENSAIT Textile Institute, 59056 Roubaix, France \\ 2 Automatique, Génie informatique, Traitement du Signal et des Images, Université Lille Nord de France, \\ F-59000 Lille, France; sebastien.thomassey@ensait.fr (S.T.); xianyi.zeng@ensait.fr (X.Z.) \\ 3 School of Textile and Clothing Engineering, Soochow University, Suzhou 215006, China \\ 4 Department of Business Administration and Textile Management, University of Boras, 50190 Boras, Sweden \\ * Correspondence: s.petchprakai@gmail.com
}

Received: 10 September 2020; Accepted: 29 September 2020; Published: 10 October 2020

check for updates

\begin{abstract}
Few studies on supply location decisions focus on enhancing triple bottom line (TBL) sustainability in supply chains; they rarely employ objective quantifiable measurements which help ensure consistent and transparent decisions or reveal relationships between business and environmental trade-off criteria. Therefore, we propose a decision-making approach for objectively selecting multi-tier supply locations based on cost and carbon dioxide equivalents $\left(\mathrm{CO}_{2} \mathrm{e}\right)$ from manufacturing, logistics, and sustainability-assurance activities, including certificate implementation, sample-checking, living wage and social security payments, and factory visits. Existing studies and practices, logic models, activity-based costing, and feedback from an application and experts help develop the approach. The approach helps users in location decisions and long-term supply chain planning by revealing relationships among factors, TBL sustainability, and potential risks. This approach also helps users evaluate whether supplier prices are too low to create environmental and social compliance. Its application demonstrates potential and flexibility in revealing both lowestand optimized-cost and $\mathrm{CO}_{2} \mathrm{e}$ supply chains, under various contexts and constraints, for different markets. Very low cost $/ \mathrm{CO}_{2} \mathrm{e}$ supply chains have proximity between supply chain stages and clean manufacturing energy. Considering sustainability-assurance activities differentiates our approach from existing studies, as the activities significantly impact supply chain cost and $\mathrm{CO}_{2} \mathrm{e}$ in low manufacturing unit scenarios.
\end{abstract}

Keywords: multi-tier supply chain planning; manufacturing location decisions; sourcing decisions; green supply network design; sustainable locations; global value chain analysis; sustainable supply chain management; carbon footprint; sustainable practices; responsible strategic management

\section{Introduction}

Making strategic decisions on where to source materials and manufacture products has become a difficult task, as products may have raw and intermediary materials from many different locations and be assembled in different places, near or far, from its customers and focal firms who govern product supply chains. As such, product supply chains can become complex and fragmented, leading to difficulty in sustainable supply chain management and visibility, two features necessary to ensure product quality and environmental/social compliance [1]. These relate to business, environmental, and social/socio-economic dimensions of sustainability, known as the Triple Bottom Line (TBL) [2]. Environmental and social issues often occur at manufacturing sites of sub-suppliers (including subcontractors and suppliers of suppliers) [3]. These issues lead to more studies towards multi-tier sustainable supply chain management involving several aspects such as managing 
suppliers and sub-suppliers, sourcing from low-risk countries and locations, governance structure, environmental performance improvement, and physical and institutional distance between focal firms and suppliers [3-8]. Moreover, some of these studies, as well as other studies on sustainable manufacturing, have mentioned positive impacts of physical and institutional proximity on sustainable practices for enhancing TBL sustainability due to, for example, short distances allowing for easy inspection and governance visits to suppliers, as well as effective local environment- and social-related laws [3,7-9]. This demonstrates that supply location decisions are important for sustainable supply chain management and sustainable practice implementation for sustainability enhancement. However, none pay attention to how to choose supply locations, configure supply networks, or compare performance of different multi-tier supply chains in order to ensure all three dimensions of TBL sustainability, as well as reputational risk avoidance at any supply stage.

Supply chain sustainability can be constrained by some location- and distance-dependent factors such as energy sources of electricity and geographical distance, which cannot be changed or significantly improved on by focal firms or their suppliers after a supply chain has been established. Therefore, multi-tier supply location decisions require considerations of factors involved in activities along product supply chains to fully drive TBL sustainability and avoid switching costs from future changes of supply locations. In this paper, the phrase 'supply location decisions' refers to the decisions of focal firms on where to source raw and intermediary materials and where to manufacture or assemble final products, rather than who manufactures the materials and products.

Existing studies on supply location decisions and network design, especially those with the simulation and modelling approaches that have been the tools for many studies on complex and multi-tier supply chains [5], pay little attention to third-tier suppliers and TBL sustainability. Most relevant existing studies consider only first-tier suppliers who produce final products, while recent studies have started to consider second-tier suppliers who supply materials to the first-tier suppliers, as shown in Table 1 . The nine articles in Table 1 were selected by reading abstracts of all retrieved articles from the Scopus database with search terms relating to design or model and manufacturing or supplier locations. 
Table 1. Comparison between this paper and recently published journal articles relating to supply location decision model and network design retrieved from the Scopus database.

\begin{tabular}{|c|c|c|c|c|c|c|c|c|}
\hline Article & Criteria and Focus & What and Where & $\begin{array}{l}\text { 3rd-Tier } \\
\text { Supplier }\end{array}$ & $\begin{array}{l}\text { 2nd-Tier } \\
\text { Supplier }\end{array}$ & $\begin{array}{l}\text { 1st-Tier } \\
\text { Supplier }\end{array}$ & Ware-House $^{1}$ & Market $^{2}$ & Re-Cycling \\
\hline [10] & $\begin{array}{l}\text { Minimize total costs and maximize } \\
\text { effectiveness of suppliers' equipment }\end{array}$ & Automotive & & $\mathrm{x}$ & $\mathrm{x}$ & $\mathrm{x}$ & $\mathrm{x}$ & \\
\hline [11] & $\begin{array}{l}\text { Minimize risks (time, reliability, } \\
\text { inventory, cost) }\end{array}$ & N/A & & & $\mathrm{x}$ & & & \\
\hline [12] & $\begin{array}{l}\text { Order frequency and lead-time impacts on } \\
\text { costs and supply chain design }\end{array}$ & Automotive, France & & $\mathrm{x}$ & $\mathrm{x}$ & $\mathrm{x}$ & $\mathrm{x}$ & \\
\hline [13] & $\begin{array}{l}\text { Reduce vehicle fuel consumption } \\
\text { and emissions }\end{array}$ & Natural honey & & & $\mathrm{x}$ & $\mathrm{x}$ & $\mathrm{x}$ & \\
\hline [14] & Optimize supply chain total costs & Cartridge, India & $\mathrm{x}$ & $\mathrm{x}$ & $\mathrm{x}$ & $\mathrm{x}$ & $x$ & $\mathrm{x}$ \\
\hline [15] & $\begin{array}{l}\text { Minimize operational and fixed costs with } \\
\text { return and demand uncertainty }\end{array}$ & $\begin{array}{l}\text { Electric appliance, } \\
\text { China }\end{array}$ & & & $\mathrm{x}$ & $\mathrm{x}$ & $\mathrm{x}$ & \\
\hline [16] & $\begin{array}{l}\text { Minimize costs, and transportation and } \\
\text { investment trade-offs }\end{array}$ & Biomass & & & $\mathrm{x}$ & $x$ & $x$ & \\
\hline [17] & $\begin{array}{l}\text { Optimize carbon emissions and costs (cap } \\
\text { and trade policy) }\end{array}$ & Generated dataset & & & $\mathrm{x}$ & $x$ & $\mathrm{x}$ & \\
\hline [18] & $\begin{array}{l}\text { Minimize outsourcing costs with } \\
\text { allocation and services to customers }\end{array}$ & Automobile, Iran & & $\mathrm{x}$ & $x$ & & $\mathrm{x}$ & \\
\hline This paper & $\begin{array}{l}\text { Minimize or optimize supply chain cost } \\
\text { and gas emissions, considering } \\
\text { sustainability-assurance activities }\end{array}$ & $\begin{array}{l}\text { T-shirt, Europe, China, } \\
\text { America }\end{array}$ & $\mathrm{x}$ & $\mathrm{x}$ & $\mathrm{x}$ & $\mathrm{x}$ & $\mathrm{x}$ & $x^{3}$ \\
\hline
\end{tabular}

${ }^{1}$ It can refer to a distribution center and includes headquarters; ${ }^{2}$ Its location may be the same as the warehouse location; ${ }^{3}$ Our approach allows users to consider a recycling location but our application does not include it. 
Table 1 also shows that only two of the recently published studies on supply location decisions and network design consider environmental sustainability and none consider social sustainability. In addition to the studies in Table 1, other related studies [19-25] similarly show that few of them considered social sustainability. This is consistent with the results of the review article by Chen et al. [26], which stated that few studies have explicitly used sustainability criteria in making facility location decisions, as well as the review article by Brandenburg et al. [27], which stated that studies on quantitative models for sustainable supply chain management have neglected the social dimension. Although we found that the Dou and Sarkis [28] study incorporated TBL factors into their offshoring outsourcing decisions model, their model is based on subjective opinions from managers for pairwise comparisons among factors rather than on objective measured performance for comparing different locations and suppliers. Objective measurement criteria are important in order to avoid possible mistakes from any one individual's subjective opinions on interpretation, misperception, and inability to process and logically optimize a large amount of data [29]. Moreover, quantifiable criteria allow data to be measured directly and input into the model, to understand users' values, preferences, requirements, and/or objectives, and to objectively choose and evaluate systems/supply chains that match the user's objectives, especially with trade-off criteria [30]. Additionally, using objective and quantifiable measures helps avoid uncertainties from subjective judgements and imprecise data [31].

For the supply location decisions, an empirical study by one of the authors [9] shows that managers of focal firms usually compare and choose supply locations and suppliers by calculating landed costs of products based on supplier quotations, together with requirements of certificates, auditing reports, and/or supplier visits by the managers in order to ensure environmental and social compliance at the suppliers' factories. However, few of them ensure that the quoted product prices by suppliers are not too low to allow the suppliers to produce high-quality products with proper environmental and social compliance. Furthermore, industrial practitioners mainly focus on waste reduction and sustainable design, including using sustainable materials for improving environmental sustainability; they overlook greenhouse gas emissions from energy sources used in manufacturing and transportation that are considered proximity manufacturing benefits on environmental and social dimensions of sustainability [32]. It is also important to consider gas emissions from managers travelling from headquarters to visit factories for price and style discussion, operation control, product inspection, and environmental and social compliance assurance, as the managers usually travel by plane, a transportation mode that emits high carbon dioxide equivalents $\left(\mathrm{CO}_{2} \mathrm{e}\right)[9]$, where $\mathrm{CO}_{2} \mathrm{e}$ is calculated from greenhouse gas emissions. Therefore, we aim to develop a supply location decision-making (SLDM) approach for finding multi-tier supply locations enhancing TBL sustainability in product supply chains with objective and quantitative measures on supply chain activities which are especially related to location- and distance-dependent factors. The SLDM approach will help answer two research questions:

1. Which supply chain configurations deliver low cost and/or $\mathrm{CO}_{2} \mathrm{e}$ for different markets?

2. Which supply chain factors, including potential risks, highly influence cost and $\mathrm{CO}_{2} \mathrm{e}$ of these configurations?

This paper has three main contributions:

1. Our SLDM approach extends the knowledge on supply chain cost and $\mathrm{CO}_{2} \mathrm{e}$ calculation by including sustainability assurance activities performed by both manufacturers and a focal firm, in addition to the manufacturing and logistics activities used in other studies.

2. This paper calls for attention to location- and distance-dependent factors from industrial practitioners and researchers for proper supply location decisions and network design and from governments and energy/logistics service providers for enhancing the factors towards TBL sustainability.

3. This paper makes practical contributions by proposing the SLDM approach with pragmatic validity applicable to a wide variety of users with different organizational contexts and preferences. 
The structure of this paper is as follows: Section 2 shows how the SLDM approach is formulated, as well as diagrams of the ten-step SLDM approach, suggested factors and computational scopes, and pathways and interconnection of factors, cost, $\mathrm{CO}_{2} \mathrm{e}$, and TBL sustainability; Section 3 explains the ten steps of the SLDM approach in detail; Section 4 demonstrates the application of the SLDM approach in viscose t-shirt supply chains; and Section 5 draws conclusion, research contributions, limitations, and implications, as well as practical and social implications.

\section{Formulation of the Supply Location Decision-Making Approach}

The development of the SLDM approach is based on industrial problems and practices from an empirical study and working experience of one of the authors, and accumulated knowledge from existing studies on location decisions, supply chain network design, and cost and environmental modelling, as shown in Table 2.

Table 2. Formulation of the supply location decision-making approach based on various studies.

\begin{tabular}{|c|c|}
\hline Sources & Features Developed in the Approach \\
\hline Author's study ${ }^{1}$ & Multi-tier, visibility, and governance focuses \\
\hline Author's study 2,3 & $\begin{array}{c}\text { The application purpose for either designing a new supply chain or evaluating existing } \\
\text { supply chains }\end{array}$ \\
\hline Author's study ${ }^{3}$ & How to objectively make manufacturing decisions for different markets \\
\hline$[13,17,20,23,24]$ & Carbon dioxide $\left(\mathrm{CO}_{2}\right)$ or greenhouse gas $(\mathrm{GHG})$ emissions as measurement criteria \\
\hline$[21,22]$ & $\begin{array}{l}\text { Measurement criteria by both cost and } \mathrm{CO}_{2} / \mathrm{GHG} \text { emissions, considering energy and } \\
\text { electricity emissions, production capacity, and material quantities }\end{array}$ \\
\hline [20] & Considering all forms of input/output factors: solid, gas, and liquid, as well as energy \\
\hline Author's study ${ }^{4},[22,23]$ & Considering logistics activities besides manufacturing activities \\
\hline Author's study ${ }^{5}$ & Considering reverse logistics for sending used products to recycling factories \\
\hline Author's study 6 & Considering sustainability assurance activities performed by manufacturers and firms \\
\hline$[23,24]$ & Considering emissions from different transportation and production technology \\
\hline Author's study ${ }^{7},[19,25]$ & Observing effects of agglomeration and proximity between supply chain stages \\
\hline [33] & Exploratory data analysis \\
\hline$[10,14,34]$ & Scenario-based technique analysis \\
\hline$[10,35]$ & Pareto frontier analysis \\
\hline [36] & Sensitivity analysis \\
\hline
\end{tabular}

Remarks: 1-7 show empirical evidences as follows: ${ }^{1}$ Most companies highly control supply chains by nominating materials specifications and sometimes suppliers; ${ }^{2}$ Most companies prefer long-term relationships with suppliers and have yearly supplier evaluation; ${ }^{3}$ A company cannot make a decision whether to split production of the same products for different main markets; ${ }^{4}$ A manager questioned whether ship transportation of distance-manufactured products was more environmentally friendly than truck transportation of proximity-manufactured products; ${ }^{5}$ A few companies send used garments to be recycled locally and abroad; ${ }^{6}$ Companies require sustainability auditing/certificate at factories, samples before running a production, as well as factory visits by their managers; ${ }^{7}$ Managers preferred locations in proximity to suppliers and markets, depending on the product.

The empirical study gave the authors insights of supply chain decisions and operations from interviewing 16 supply chain, purchasing, and sustainability control managers on why and how they choose local, nearshoring, and offshoring supply locations, calculate landed costs, ensure high product quality and sustainability compliances, and operate businesses with their suppliers and customers. The empirical study helps develop differentiating features of the SLDM approach from other existing studies, shown in Table 2. Some results of the empirical study are published in Sirilertsuwan, Hjelmgren and Ekwall [9]. Moreover, the insights on studied subject help enhance this research's validity by aiding the authors in understanding what caused the research findings during interpretation and analysis [37].

The SLDM approach consists of ten steps shown in Figure 1, described in detail in Section 3. The approach adopts two widely used objective measures from existing studies for comparing all possible supply chain configurations: cost and $\mathrm{CO}_{2} \mathrm{e}$ from normalized greenhouse gas emissions. The approach adopts multivariate graphical and non-graphical exploratory data analysis [33], such as cross tabulation, stacked column charts, and scatter plots, to reveal important factors, agglomeration and proximity between supply chain stages, and the lowest or optimized cost and $\mathrm{CO}_{2} \mathrm{e}$ supply chains to be selected. In the scatter plots, cost and $\mathrm{CO}_{2}$ e trade-offs are visualized, and optimized cost 
and $\mathrm{CO}_{2} \mathrm{e}$ supply chains are revealed on the Pareto frontier. This helps inform users (i.e., decision makers) how an improvement in cost may negatively affect $\mathrm{CO}_{2} \mathrm{e}$, and vice-versa, when making their decisions [35] regarding a preferred supply chain matching user's cost and $\mathrm{CO}_{2} \mathrm{e}$ preferences and constraints for this research. Our approach focuses on finding a low-cost and $\mathrm{CO}_{2} \mathrm{e}$ supply chain from visualization techniques of Pareto frontiers rather than mathematical methods; therefore, we do not show computational methods for multi-dimensional sets relating to Pareto optimization. However, readers can further learn about computational methods from the Lotov [35] book and the Perez Loaiza, Olivares-Benitez, Miranda Gonzalez, Guerrero Campanur and Martinez Flores [10] study. Scenario analysis, which is a tool for strategic analysis [34], is adopted to help users better understand the causality of events and critical uncertainties as risk factors impacting target outcomes: the lowest or optimized cost and $\mathrm{CO}_{2} \mathrm{e}$ supply chains. The approach also adopts sensitivity analysis [36] to analyze robustness on how changes or imprecision of input factors potentially affect the outcomes. Both scenario and sensitivity analyses help decision making with long-term planning [38]. Additionally, sensitivity analysis has also been used as a validation procedure in some models to evaluate supply chain performance [31].

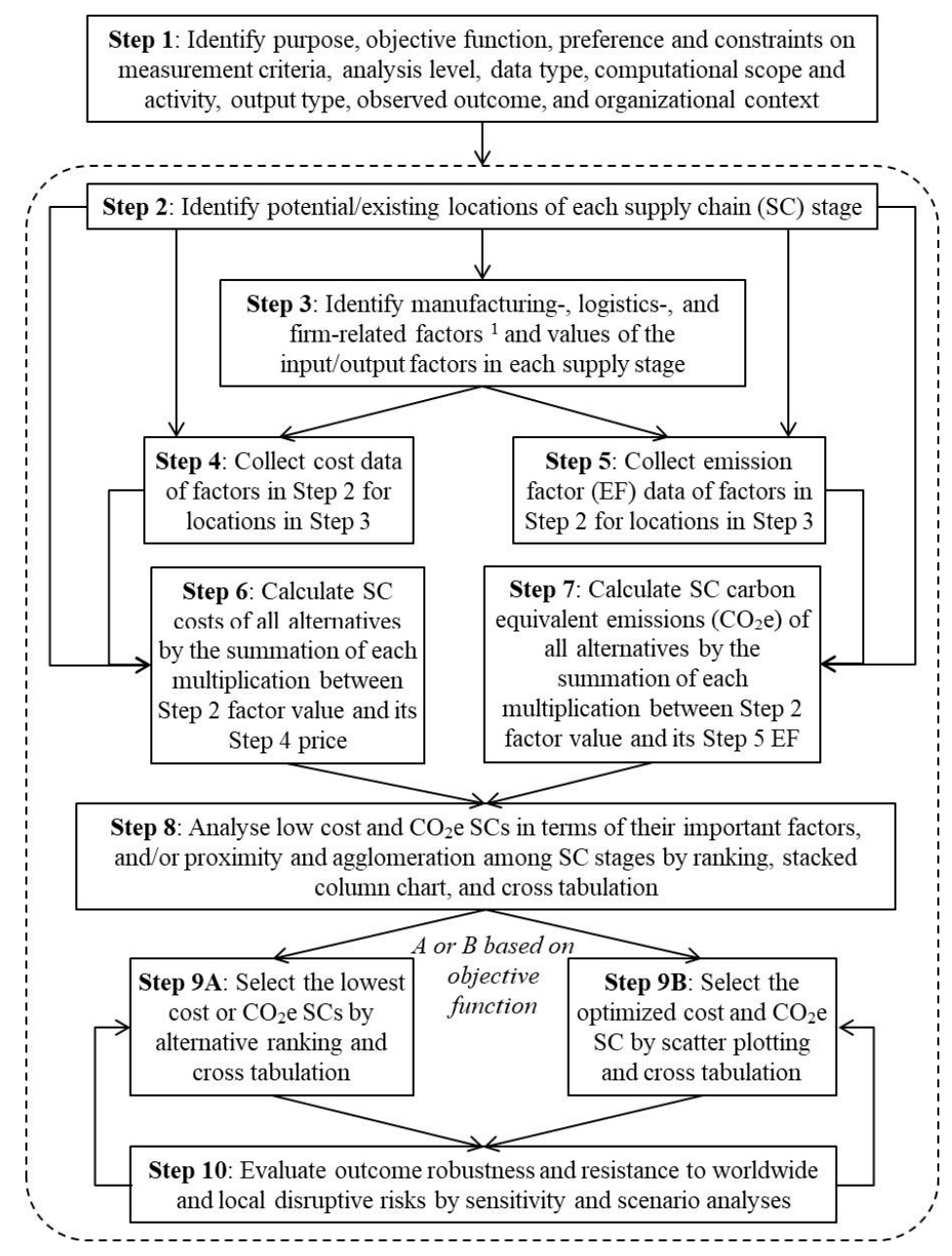

Figure 1. The ten-step supply location decision-making approach. Remarks: Data from Step 3 to Step 5 are stored in its matrix and linked to its coefficient matrix whose values vary during sensitivity and scenario analyses; ${ }^{1}$ Suggested factors are shown in Figure 2.

Figure 2 presents a summary of the ten steps, supply chain stages, supply chain activities and their factors relating to manufacturing and remanufacturing, logistics and reverse-logistics, and focal firms for supply chain cost and $\mathrm{CO}_{2} \mathrm{e}$ calculation. The factors and activities are from studies in 
Table 2 and from authors after applying logic models and an activity-based costing (ABC) method in product supply chains. Logic models $[39,40]$ are used as tools for identifying inputs, activities, outputs, and outcomes, as well as their pathways and interconnections shown in Figure 3, while ABC is used for allocating indirect costs and $\mathrm{CO}_{2} \mathrm{e}$ to all manufactured units and is widely used in studies relating to supply chain decisions on organization performance, profitability, cost, productivity, and processes [41]. Furthermore, iteratively formulating and applying older versions of the approach into viscose t-shirt supply chains, as well as feedback from experts, also helps improve the lists of factors and the steps of the approach shown in Figure 2. We improved the approach by repeatedly comparing results with existing studies and theories to enhance validity. This process has been used in other studies to strengthen their findings [7]. Moreover, we also reflected what works in practice to produce intended outcomes for enhancing pragmatic validity [42].

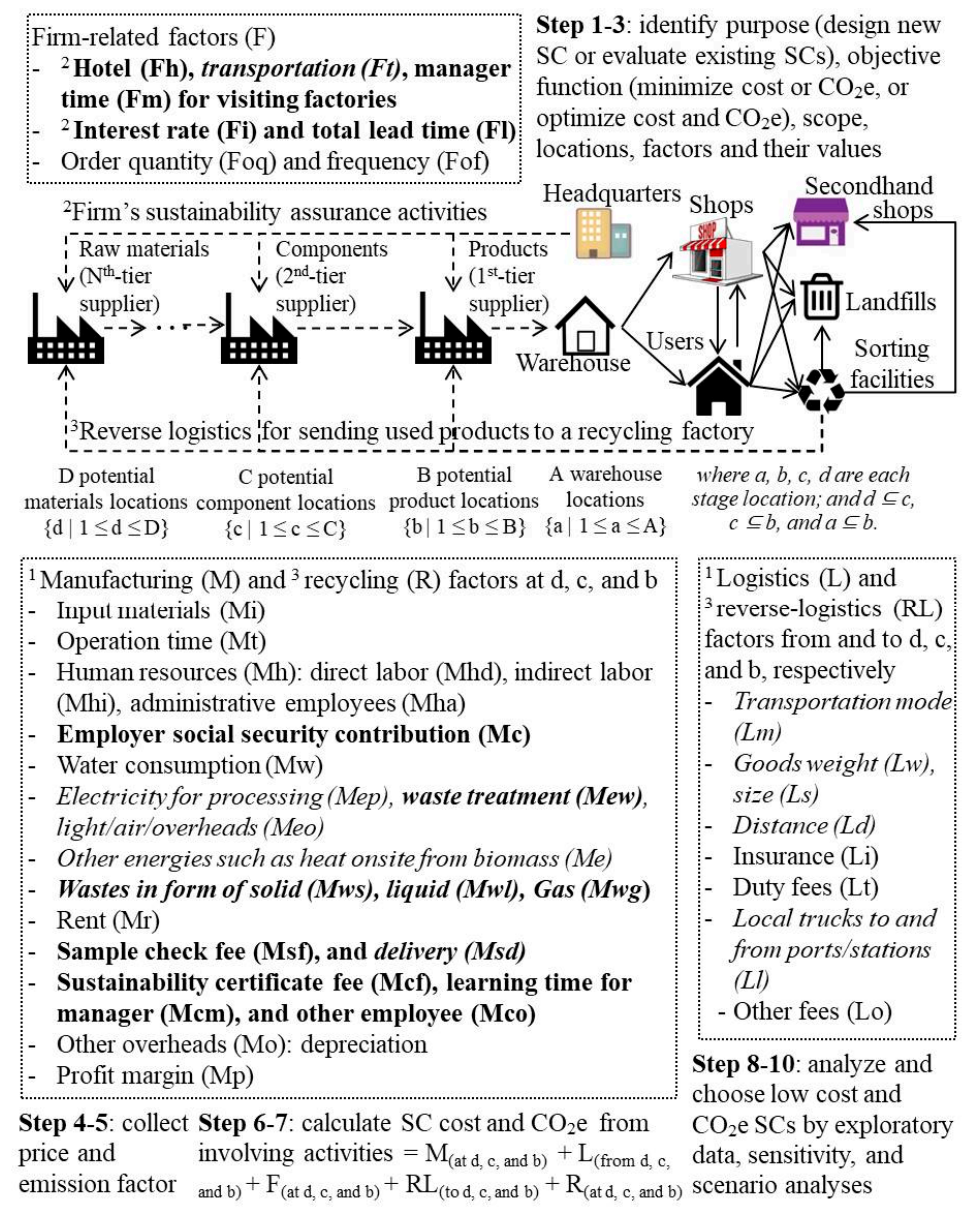

Figure 2. Factors, activities, and summarized steps in the proposed supply location decision-making approach with cost and carbon dioxide equivalent $\left(\mathrm{CO}_{2} \mathrm{e}\right)$ criteria. Remarks: Bold factors are from sustainability assurance activities, differentiating this approach from traditional cost and/or $\mathrm{CO}_{2} \mathrm{e}$ calculation; italicized factors involve $\mathrm{CO}_{2}$ e calculation; dashed arrows presents activities and supply chain stages whose cost and $\mathrm{CO}_{2} \mathrm{e}$ are location- and distance-dependent for different supply locations; ${ }^{1}$ for the landed scope; ${ }^{2}$ added activities into the landed scope for the firm scope; ${ }^{3}$ added activities into the landed or firm scope for the recycling scope.

In accordance with Figure 3, users who use the SLDM approach will understand which factors, from which activities performed by whom, influence which outcomes, aiding strategic supply chain planning and management. We consider cost and $\mathrm{CO}_{2} \mathrm{e}$ outputs to be intermediate outcomes, and TBL sustainability to be a long-term outcome. The highlights in Figure 3 are how factors from sustainability 
assurance activities ultimately impact TBL sustainability, and how future socio-economic measurement criteria could be added.

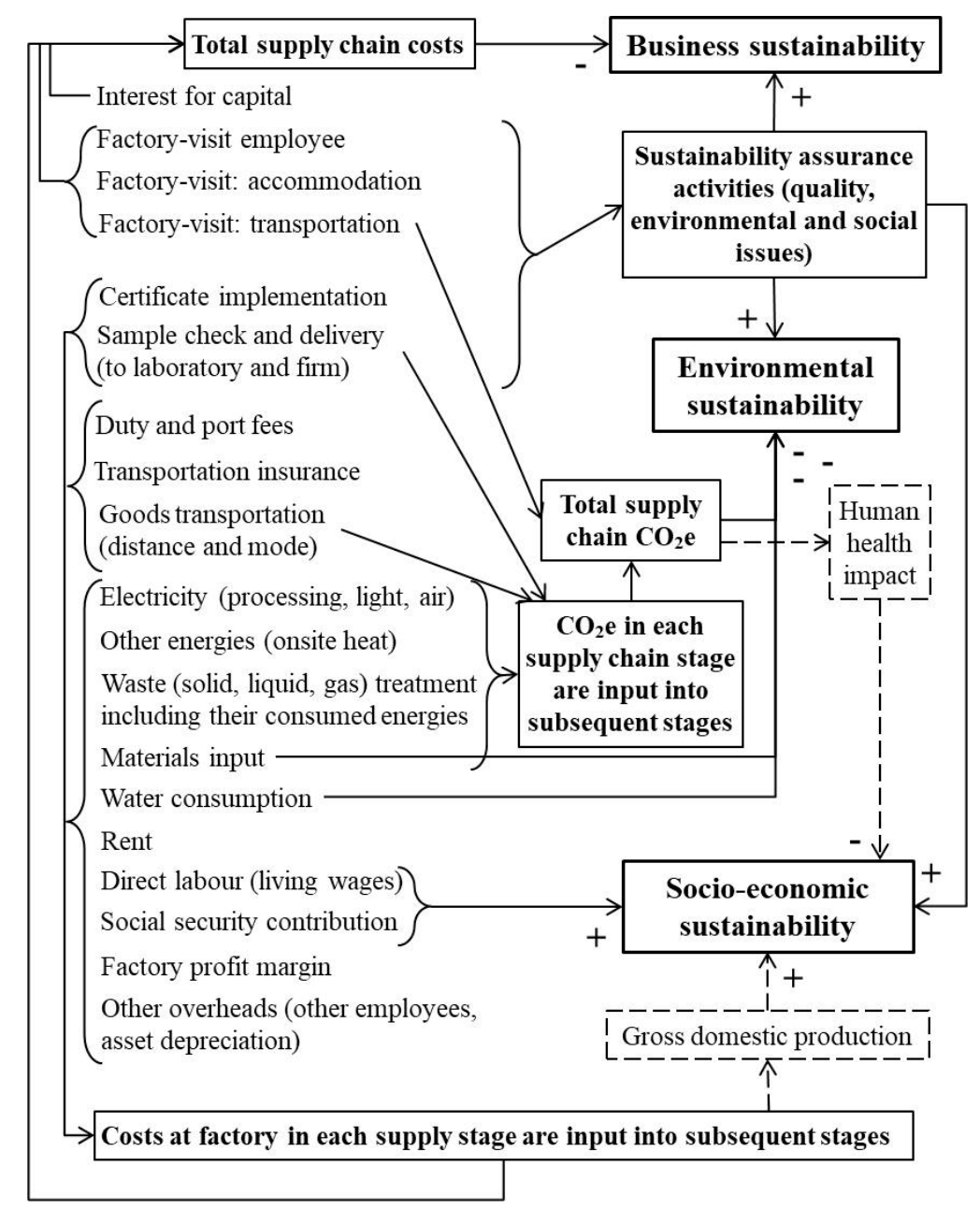

Figure 3. Pathways and interconnection among input and output factors from manufacturing, logistics, and firm's activities, cost and $\mathrm{CO}_{2} \mathrm{e}$ measures, and the business, environmental, and socio-economic sustainability. Remarks: Dashed boxes and arrows present possible socio-economic measures for future research.

Our SLDM approach is normative in terms of required sustainability assurance activities performed by manufactures to ensure proper environmental and social compliance because minimum requirements for social and environmental standards at manufacturing sites can help sustainable supply chain management [43]. With our approach, focal firms can estimate prices of materials and products that are produced with sustainability assurance activities for TBL sustainability. If quoted prices by manufacturers are significantly lower than estimated prices, it is possible that the manufacturers cannot produce high product quality with good environmental and social compliance, as mentioned by managers from a prior empirical study performed by the author.

The SLDM approach has three cost and $\mathrm{CO}_{2}$ e computation scopes. The first is 'the landed scope,' which is similar to traditional landed cost and $\mathrm{CO}_{2} \mathrm{e}$ calculation in terms of accumulating costs and $\mathrm{CO}_{2} \mathrm{e}$ from suppliers to warehouse in a market. However, our landed scope includes sustainability assurance activities performed by manufacturers in the cost and $\mathrm{CO}_{2} \mathrm{e}$ calculation, leading to differentiation from the traditional calculation. The activities relate to the bolded manufacturing and recycling factors in Figure 2. In addition to manufacturers, focal firms also perform sustainability-assurance activities, including visiting factories and paying interest to gain capital and cash flow for business operations. 
Different manufacturing locations vary cost and $\mathrm{CO}_{2} \mathrm{e}$ generated by these activities. Therefore, if focal firms perform these sustainability assurance activities, supply chain cost and $\mathrm{CO}_{2} \mathrm{e}$ calculations have to include cost and $\mathrm{CO}_{2} \mathrm{e}$ from these activities into the landed scope, hereafter referred to as 'the firm scope.' All sustainability assurance activities performed by both manufacturers and focal firms differentiate our SLDM approach from other studies and quantitative approaches for location decisions, as well as traditional cost and environmental computations. If products are recycled at one of the factories in any supply stage(s) after the consumer use phase, cost and $\mathrm{CO}_{2} \mathrm{e}$ from sending used products back to the factory and from recycling processes will be included into the landed scope or the firm scope, to be referred to as 'the recycling scope.'

\section{The Ten-Step Supply Location Decision-Making Approach}

All ten steps of the SLDM approach in Figure 1 are explained below.

\subsection{Step 1 to Step 3: Identification}

Step 1 involves identifying all nine correlated aspects shown in Figure 4. These aspects help users identify what they want from and can do with the SLDM approach. Figure 4 shows flexibility and applicability of the approach to wide user groups. As shown in Figure 1 with the dashed frame, Step 1 is crucial for conducting the other steps of the SLDM approach to help align all steps and all possible supply chains to be comparable, ensuring validity.

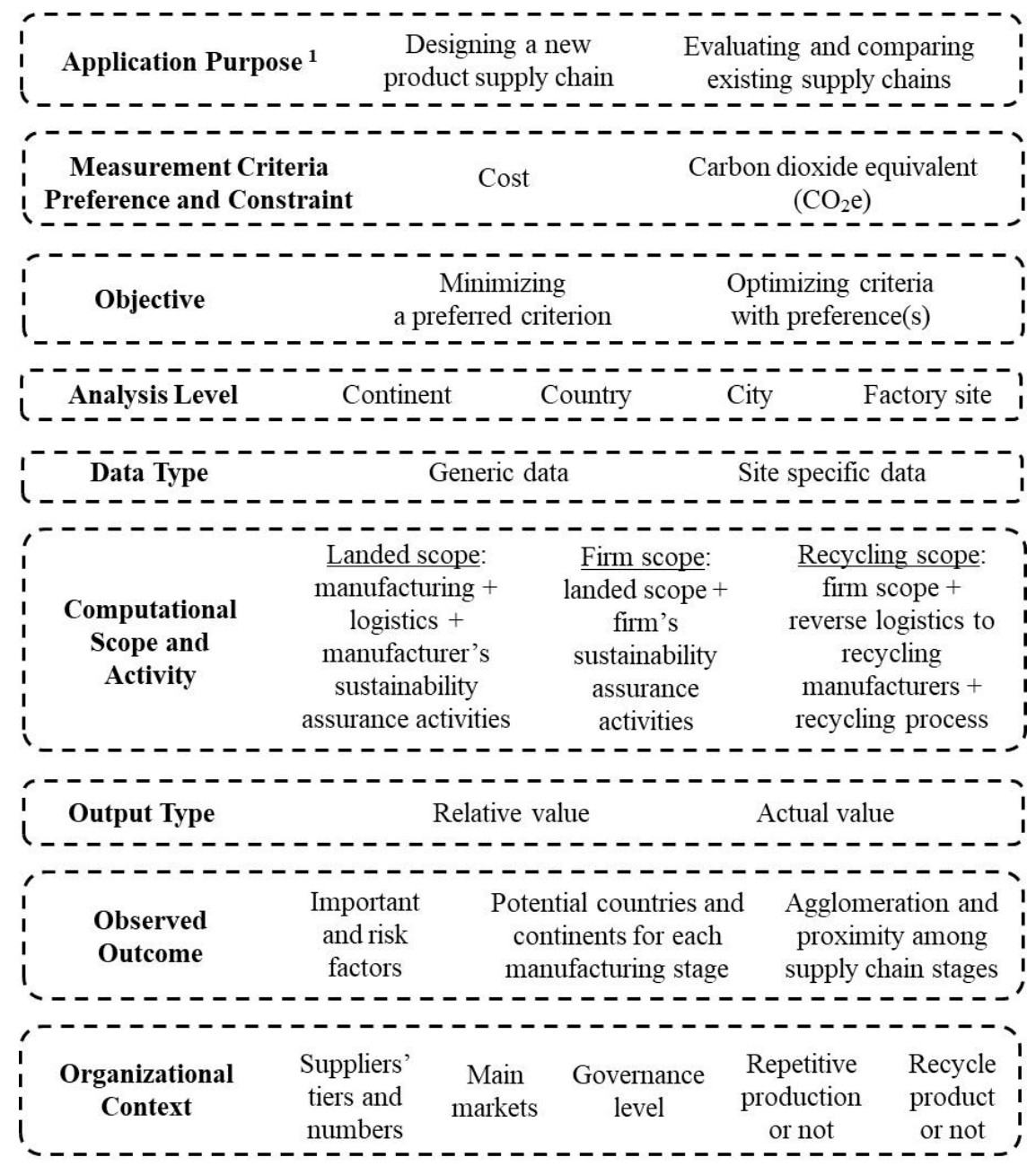

Figure 4. Aspects to be identified in Step 1. Remarks: ${ }^{1}$ With specifying which product to be produced at which quantity per a production batch. 
In order to generate all possible supply chains to be compared, Step 2 involves identifying potential or existing locations of each supplier in each supply stage depending on the application purpose. The sampled potential supply locations are based on a country's reputation on certain products, availability of suppliers and industrial setup, possible production capacity, and the proximity to natural resources, warehouses, and prior and subsequent supply stages.

As seen in Figure 4, supply chain cost and $\mathrm{CO}_{2} \mathrm{e}$ of all possible supply chains to be compared can be either relative or actual total values, which influences Step 3. The relative values can fulfil the aim of the SLDM approach by focusing on location- and distance-dependent factors from activities generating different cost and $\mathrm{CO}_{2} \mathrm{e}$ among different supply locations. Users can calculate relative values of cost and $\mathrm{CO}_{2} \mathrm{e}$ based on the factors in Figure 2. On the other hand, the actual values can be calculated by including additional activities such as distribution, retailing, consumption, waste management, product design and development, and sales and marketing. Users can use logic models and ABC to reveal these factors. Amounts of manufacturing inputs and outputs, as well as distance and time for sample, product, and manager transportations, are gathered in Step 3. Data for these factors are stored in manufacturing-, logistics-, firm-, reverse logistics-, and recycling-data matrices, whose cells are multiplied with coefficient values from manufacturing-, logistics-, and firm-coefficient matrices. Every data matrix in Step 3 to Step 5 has its own coefficient matrix. The coefficients are beneficial to sensitivity and scenario analyses in Step 10 as they allow for easy changing of factor values and comparison, and are initially set to values of 1.

\subsection{Step 4 and Step 5: Data Collection on Cost and Emission Factors}

Cost and Emission factors (EFs) of the identified factors in Step 3 for each potential location in Step 2 are stored in cost and EF matrices whose cells are multiplied with coefficient values from their own cost- and EF-coefficient matrices. EFs of the main GHGs to be collected are $\mathrm{CO}_{2}, \mathrm{CH}_{4}$, and $\mathrm{N}_{2} \mathrm{O}$ EFs, which can be found online, for example, on the websites of Greenhouse Gas Protocol [44] and The Intergovernmental Panel on Climate Change (IPCC) [45]. Users need to collect EFs for different locations from the same source for comparable results. The $\mathrm{CO}_{2}, \mathrm{CH}_{4}$, and $\mathrm{N}_{2} \mathrm{O}$ EFs are normalized into the same unit, which is $\mathrm{CO}_{2} \mathrm{e}$, by multiplying the Global Warming Potential (GWP) by the $\mathrm{CO}_{2}$, $\mathrm{CH}_{4}$, and $\mathrm{N}_{2} \mathrm{O}$ EFs, as shown in Equation (1).

$$
\mathrm{CO}_{2} \mathrm{e}=\left(\left(\mathrm{EF}_{\mathrm{CO} 2} \times \mathrm{GWP}_{\mathrm{CO} 2}\right)+\left(\mathrm{EF}_{\mathrm{CH} 4} \times \mathrm{GWP}_{\mathrm{CH} 4}\right)+\left(\mathrm{EF}_{\mathrm{N} 2 \mathrm{O}} \times \mathrm{GWP}_{\mathrm{N} 2 \mathrm{O}}\right)\right)
$$

where $\mathrm{GWP}_{\mathrm{CO} 2}, \mathrm{GWP}_{\mathrm{CH} 4}$, and $\mathrm{GWP}_{\mathrm{N} 2 \mathrm{O}}$ from the IPCC fifth assessment report are 1, 28, and 265, respectively.

\subsection{Step 6 and Step 7: Supply Chain Cost and $\mathrm{CO}_{2}$ e Computation}

Each of the possible supply chains has its supply chain cost or $\mathrm{CO}_{2} \mathrm{e}$ of producing one-batch products by summing all factor costs from all activities within the identified computational scope in Step 1. $\mathrm{CO}_{2} \mathrm{e}$ computation involves the italicized factors shown in Figure 2. Based on the identified scope, activities, and the number of supply stages and suppliers in each stage, supply chain cost and $\mathrm{CO}_{2} \mathrm{e}$ of the three scopes can be calculated by Equation (2).

$$
\text { Supply chain cost or } \mathrm{CO} 2 e=\sum_{i=1}^{N} \sum_{j=1}^{S}\left(C M_{i j}+C L_{i j}+C F_{i j}+C R L_{i j}+C R_{i j}\right)
$$

where $i$ represents each supply stage of $N$, the total number of supply stages; $j$ represents each supplier in each supply stage, and $S$ is the maximum number of the total number of required suppliers in each $i^{\text {th }}$ supply stage; $C M, C L, C F, C R L$, and $C R$ are accumulated costs or $\mathrm{CO}_{2} \mathrm{e}$ of factors from activities relating to manufacturing $(\mathrm{CM})$ at a factory, logistics $(\mathrm{CL})$ from a factory, firms' sustainability assurance (CF) involving a factory, reverse-logistics (CRL) to a factory, and recycling process (CR). 
Each factor cost or $\mathrm{CO}_{2} \mathrm{e}$ from the activities is calculated by multiplying its factor value from Step 3 with its cost rate from Step 4, or its normalized $\mathrm{CO}_{2}, \mathrm{CH}_{4}$, and $\mathrm{N}_{2} \mathrm{O}$ EFs from Step 5. Indirect and fixed costs or $\mathrm{CO}_{2} \mathrm{e}$ are allocated into a production batch using $\mathrm{ABC}$. Time-based costs are allocated by using factory operating time per day and per month, rather than $24 \mathrm{~h}$ and 30 days, respectively.

\subsection{Step 8: Supply Chain Analysis on Important Factors and Proximity among Stages}

This step adopts exploratory data analysis to reveal important factors influencing supply chain costs and $\mathrm{CO}_{2} \mathrm{e}$, as well as which supply chain stages should be agglomerated or be in proximity to each other in order to achieve very low cost and $\mathrm{CO}_{2} \mathrm{e}$ supply chains, and ultimately what those locations are. Therefore, the SLDM approach helps users not only with supply location decisions, but also with supply chain planning on possible future disruptions and investing resources to find and establish relationships with proper suppliers from the locations that generate very low cost and $\mathrm{CO}_{2} \mathrm{e}$. Agglomeration between supply stages in the approach refers to either two suppliers for subsequent supply stages located in the same area (resembling business clusters), or one supplier performing manufacturing of two supply stages (resembling vertical integration).

All possible supply chains are ranked by cost and $\mathrm{CO}_{2} \mathrm{e}$ from the lowest to the highest values. Users choose a set of supply chains to be analyzed based on their cost and $\mathrm{CO}_{2}$ e preferences, as well as any constraints. After that, stacked column charts of the supply chains are plotted to reveal important factors influencing total costs and $\mathrm{CO}_{2} \mathrm{e}$. Cross-tabulation of agglomeration or proximity between two supply chain stages and their common countries or continents shows which supply chain stages should be agglomerated or located in proximity in order to achieve supply chains with preferred cost and $\mathrm{CO}_{2} \mathrm{e}$. Cross-tabulation can also be used to compare results of different markets and computational scopes in order to find their common supply chains. Comparing results of different computational scopes also aids users in seeing the feasibility of adopting a firm's sustainability assurance and recycling activities.

\subsection{Step 9: Supply Chain Selection Based on an Objective Function}

As shown in Figure 1, Step 9 has options A and B. Option A is for selecting a supply chain with the lowest cost or the lowest $\mathrm{CO}_{2} \mathrm{e}$ that are known from supply chain cost and $\mathrm{CO}_{2}$ e rankings in Step 8, while Option $\mathrm{B}$ is for selecting an optimized low-cost and $\mathrm{CO}_{2}$ e supply chain by scatter plotting. The scatter plot between cost and $\mathrm{CO}_{2} \mathrm{e}$ of all alternatives reveals a Pareto frontier containing optimized low cost and $\mathrm{CO}_{2}$ e supply chains, which represents cost and $\mathrm{CO}_{2} \mathrm{e}$ trade-off solutions for conflicting multi-criteria [35]. The optimized supply chains on the Pareto frontier can be found automatically by coding Pareto computational methods into a program. Alternatively, optimized supply chains can be found manually by identifying the supply chain with the lowest value of a selected criterion on either the x-axis or y-axis, and then identifying the next optimized supply chain with the next lowest value of the same criterion from supply chains located between the previously identified supply chain and zero in the scatter plot. Repeat this until reaching the supply chain with the lowest value of the other criterion. Users can choose a final supply chain based on their cost and $\mathrm{CO}_{2}$ e preferences and constraints. Users can also choose a set of optimized supply chains to look for suppliers and then use other criteria to choose a final supply chain, such as relatively superior knowledge and technology, optimal collaboration or existing relationships with suppliers, government support and trade policies, and political situations of manufacturing areas. As shown in Figure 1, results of sensitivity and scenario analyses in Step 10 will serve as feedback to this step to help in choosing a supply chain which has high resistance to risk and changing environments. Additionally, different markets may have common and different optimized supply chains which can be revealed by cross-tabulation.

\subsection{Step 10: Evaluation on Outcome Robustness and Resistance to Risks}

This step evaluates the robustness and resistance to risk of outcomes and the selected supply chains by sensitivity and scenario analyses. Various what-if situations are generated by changing 
coefficients of each factor value possibly affecting supply chains. This helps users foresee risk impact on supply chain/location attractiveness and competitiveness [38] in terms of cost and $\mathrm{CO}_{2} \mathrm{e}$.

Sensitivity analysis is performed by changing coefficients of each factor value in either all locations at once, or each location at a time, to imitate global and local disruptions, respectively. The results of the sensitivity analysis help users recognize important factors, including risk factors, which make the selected supply chains in Step 9 less competitive. Risk factors are those for which small changes in factor coefficients cause the selected supply chain to lose its cost and $\mathrm{CO}_{2} \mathrm{e}$ competitiveness or to violate the user's cost or $\mathrm{CO}_{2}$ e preferences and constraints.

Scenario analysis is performed by changing a coefficient of a factor at different levels to represent different scenarios of possible future problems which arise from current situations, such as trade wars, and from important factors revealed in Step 8 and in this step by the sensitivity analysis. Common results of different scenarios should be chosen because they have high resistance to changing environments that help avoid the switching costs of changing suppliers for new supply chains in the future and ensure smooth operations [46].

\section{Application for Selecting Supply Locations of Viscose T-Shirts}

We choose to apply our proposed approach in the textile and clothing industry, as we have expertise and insights into the industry, benefiting the application. Viscose $t$-shirts were selected due to the possibility to generate several possible supply chains and scenarios. T-shirts are a basic product without specialized manufacturing-skill requirements, affording a high degree of flexibility in finding various potential manufacturing locations in proximity to or far from warehouse and materials supply locations. Together with worldwide viscose fiber production with controlled quality due to man-made materials, viscose $t$-shirts can have several comparable possible supply chain configurations. Regarding several possible scenarios, $t$-shirts allow both repetitive and non-repetitive production scenarios because $t$-shirts are basic products that usually have continuous demand, except for some styles and materials with low sales. Of note, details of calculation, data inputs, and results are shown in the Appendix A-C.

\subsection{Step1: Identification of Core Aspects}

We identify core aspects shown in Figure 4. The purpose of this application is to design a new supply chain for producing $1800 \mathrm{t}$-shirts to serve the main market in Europe with consideration of future markets in US and China. We assume that headquarters and a warehouse of the focal firm are at the same location in Germany because it is the main market for the European clothing industry [47]. The objective is to optimize cost and $\mathrm{CO}_{2} \mathrm{e}$ within the 10,000-euro budget and with the least possible $\mathrm{CO}_{2} \mathrm{e}$. Analysis levels for proximity and agglomeration between supply chain stages are at the country and continent levels. Due to a new supply chain, there are no specific and previous data from suppliers to be collected. Therefore, all collected data are generic and publicly available at the country or city level. The computational scope is the firm scope based on industrial practices of visiting factories regularly and rarely having in-house recycling programs. Additionally, headquarters have in-house garment design with nominated materials and suppliers, and as such, suppliers must send samples to headquarters and laboratories for quality assurance. The computational outputs are relative values of supply chain cost and $\mathrm{CO}_{2}$ e. Regarding organizational contexts, there are three supply stages with one major supplier in each stage. As mentioned before, as viscose $t$-shirts have the possibility of low sales, the cost and $\mathrm{CO}_{2} \mathrm{e}$ computation will start with a one-batch scenario followed by six-, twelve-, and eighteen-batch scenarios for one-, two-, and three-year sales of the same product, respectively. We will observe important factors, potential locations of each supply stage, and proximity and agglomeration among supply chain stages. 


\subsection{Step 2: Location Identification}

Starting with fiber production locations, we assumed six potential locations of fiber manufacturing based on manufacturing locations of the Lenzing Company, which uses environmentally friendly manufacturing technology. Fabric and garment manufacturing have the same potential locations as fiber manufacturing and warehouse and headquarters in Germany, as shown in Figure 5. The other potential fabric and garment manufacturing locations are selected due to country reputation and availability of viscose fabric and t-shirt manufacturing from online searches. To observe the effects of local, nearshoring, and offshoring manufacturing to supply chain cost and $\mathrm{CO}_{2} \mathrm{e}$, we sampled the locations based on cost and distance to Germany. In total, there are 1536 potential supply chain configurations from 6 fiber manufacturing locations, 16 fabric manufacturing locations, and 16 garment manufacturing locations.

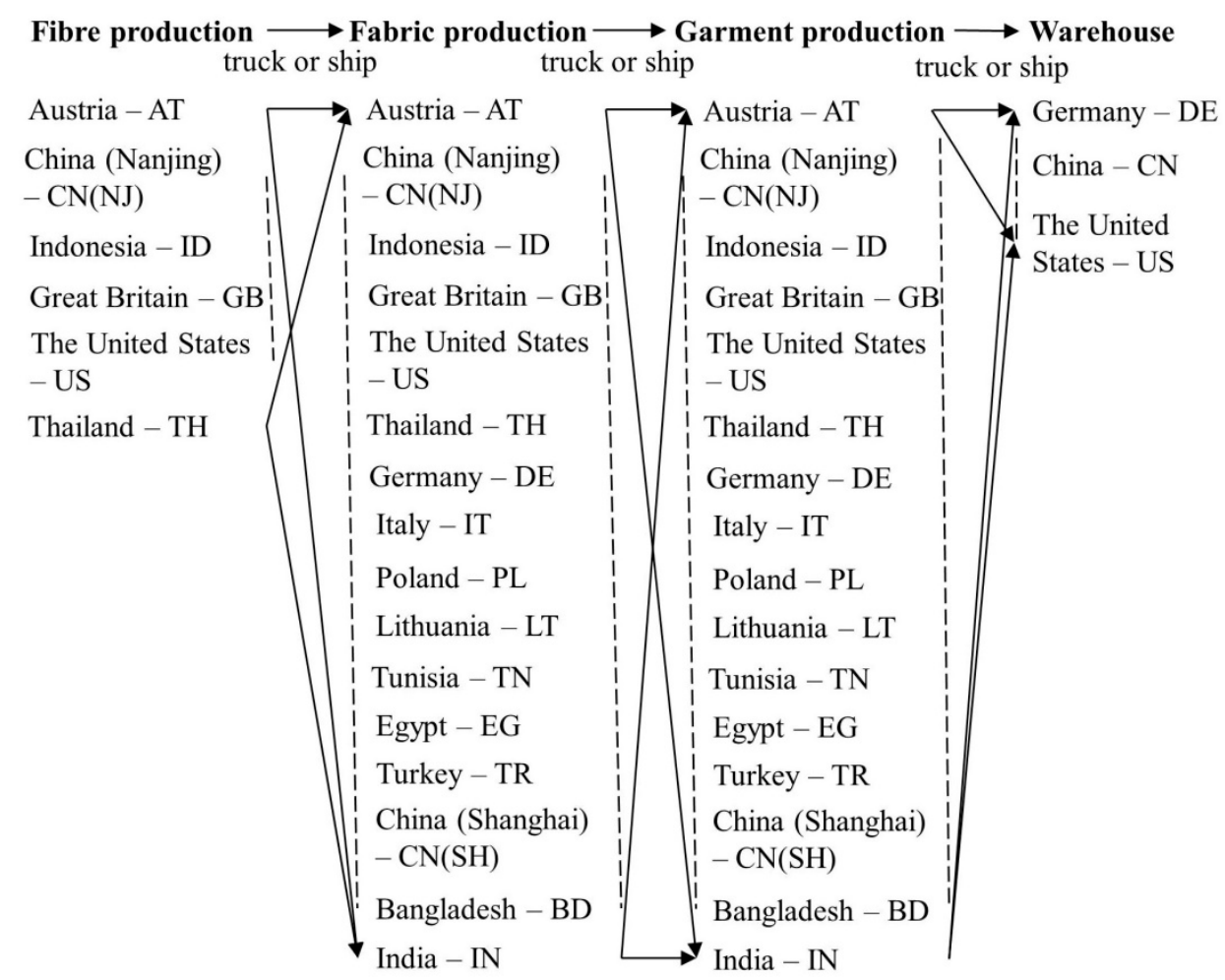

Figure 5. Potential manufacturing locations and their acronyms for each supply stage of t-shirt supply chains.

Hereafter, acronyms of locations in Figure 5 will be used when mentioning three-tier supply locations of a supply chain. For example, AT-EG-LT refers to fiber manufacturing in Austria, fabric manufacturing in Egypt, and garment manufacturing in Lithuania.

\subsection{Step 3: Factor and Their Value Identification}

In accordance with the firm scope identified in Step 1, we considered factors shown in Figure 2, from fiber, fabric, to garment manufacturing stages. Fabric manufacturing includes thread spinning, knitting, and dyeing. Garment manufacturing includes cutting and sewing. The inputs and outputs of each process are calculated based on inventory data in the Angelstam, et al. [48] study by starting with $360 \mathrm{~kg}$ of $1800 \mathrm{t}$-shirts. This allows us to find the transported weights of fabrics and fibers, which are 442.64 and $540.02 \mathrm{~kg}$, respectively. The fiber quantity is used for finding energy use in fiber manufacturing based on the Shen and Patel [49] study. Fabric dyeing and cutting machine capacities are based on studies of Amin [50] and Phakphonhamin and Chudokmai [51]. Operation time is assumed to be $6.48 \mathrm{~min}$ per t-shirt [52]. 
Based on Step 2, only Austrian fiber manufacturing uses the environmentally friendly manufacturing technology, which provides much lower amounts of non-renewable energy use (NREU) than the normal technology in the other locations. We also consider cost and $\mathrm{CO}_{2} \mathrm{e}$ from electricity used in wastewater treatment that are calculated based on the study of Yin et al. [53]. Distance and delivery time between locations for assigned transportation mode are obtained from Searates.com, a logistics provider's website. Trucking is used for domestic transportation in China and between factories and ports for international transportation by ship, as well as international transportation between Germany, Italy, Poland, and Lithuania. International transportation between the other locations uses shipping. More manufacturing data are in Tables A1-A8 in Appendix A.

\subsection{Step 4 and Step 5: Data Collection of Cost and Emission Factors}

We searched for the costs of factors related to Figure 2 online in 2019. Costs of employees to train themselves and write reports for the certificate and auditing, as well as costs of managers to visit factories, are calculated based on employees' time spent on the activities; the costs are allocated into one-batch production using $\mathrm{ABC}$, based on the number of years that the certificate is valid, factory working time for one-batch production, and the number of manufacturing batches before a new factory visit by a manager from headquarters. Cost data in details are in Tables A9-A22 in Appendix A.

Electricity EFs of each country are obtained from emissions per kWh of electricity consumed shown in the Brander et al. [54] technical paper. EFs of NREU, renewable energy use (REU), landfill gas, good transportation by truck and ship, and passenger car for domestic travelling of managers to visit factories are from an excel sheet provided by Greenhouse Gas Protocol [44]. Without using EFs for $\mathrm{CO}_{2} \mathrm{e}$ calculation, $\mathrm{kgCO}_{2} \mathrm{e}$ of sample delivery and flights for a manager to visit factories are from the DHL carbon calculator on its website, as well as from the flight search function of the FlyGreen website [55].

\subsection{Step 6 and Step 7: Supply Chain Cost and $\mathrm{CO}_{2}$ e Computation}

We multiplied factor values from Step 3 by cost rates and EFs from Steps 4 and 5, respectively, to get costs and $\mathrm{CO}_{2} \mathrm{e}$ from manufacturing, logistics, and firm activities involved in each supply stage. Detailed calculation of these costs and $\mathrm{CO}_{2} \mathrm{e}$ is shown in Appendix B. After that, the costs and $\mathrm{CO}_{2} \mathrm{e}$ are input into Equation (2) to compute supply chain costs and $\mathrm{CO}_{2} \mathrm{e}$ of all 1536 possible supply chains for the European market. As we stated in Step 1 regarding the future markets in China and US, we also calculated another two sets of costs and $\mathrm{CO}_{2} \mathrm{e}$ of 1536 possible supply chains for the Chinese and US markets. Selected results of the three markets are shown in the next steps.

\subsection{Step 8: Supply Chain Analysis}

In this step, we focus on only the current market in Europe; therefore, we ranked all 1536 possible supply chains of the European market from the lowest to the highest values of cost and $\mathrm{CO}_{2} \mathrm{e}$. After that, we select the $1 \%$ lowest-value supply chains, as shown in Table A23 in Appendix C, to analyze important factors as well as potential locations and proximity among supply chain stages.

Stacked column charts are used to break down costs and $\mathrm{CO}_{2}$ e from all activities along each supply chain to reveal which factors significantly influence the supply chain costs and $\mathrm{CO}_{2} \mathrm{e}$, as shown in Figures A1 and A2 in Appendix C. Cost of visiting factories (in terms of a manager's compensation) is the greatest influence of the supply chain cost, followed by fiber price, fiber transport, transportation cost of visiting factories, and fabric overhead of administrative employees, including manager and their social security contribution. The high costs of manager compensation and transportation to visit factories can be reduced by repetitive manufacturing before a new factory visit. The effects of repetitive manufacturing on costs and $\mathrm{CO}_{2} \mathrm{e}$ will be shown in Step 10 during the scenario analysis on different numbers of manufacturing batches. Of note, the 1\% lowest-cost supply chains have agglomerated fabric and t-shirt manufacturing locations in Egypt, Tunisia, Turkey, and Poland, which are relatively lower cost countries located in proximity to warehouse and headquarters in Germany. The results 
highlight that paying relatively high transportation cost of materials to have components and product manufacturing in a relatively low cost country located in proximity to the market helps achieve very low cost supply chains. This contributes to the Weber [25] theory by adding international location aspects with different manufacturing costs and three supply stages.

The stacked column chart of the $1 \%$ lowest- $\mathrm{CO}_{2} \mathrm{e}$ supply chains shows that fiber REU significantly influences the firm-scope $\mathrm{CO}_{2} \mathrm{e}$ of the 16 lowest $\mathrm{CO}_{2} \mathrm{e}$ supply chains, followed by fiber NREU. The results highlight the importance of environmentally friendly technology in fiber manufacturing to achieve very low $\mathrm{CO}_{2} \mathrm{e}$. All 16 lowest $\mathrm{CO}_{2} \mathrm{e}$ supply chains have fiber manufacturing in Austria, the only location with environmentally friendly technology. Electricity EFs and proximity to Germany, implying lower transportation emissions, are important factors to fabric and garment manufacturing locations of very low $\mathrm{CO}_{2} \mathrm{e}$ supply chains. This is evidenced by the fact that half of the 16 lowest $\mathrm{CO}_{2} \mathrm{e}$ supply chains have fabric and garment manufacturing in Germany rather than America, Thailand, and Bangladesh, whose electricity EFs are smaller than Germany's. The $\mathrm{CO}_{2} \mathrm{e}$ stacked column chart also demonstrates that transportation $\mathrm{CO}_{2} \mathrm{e}$ rates are much lower than manufacturing $\mathrm{CO}_{2}$ e rates. This calls for attention to proper interpretations on the reduction of GHG emissions in some countries, such as high reduction of European industrial GHG emissions [56]. The reduction can be from migrating European industries and industrial emissions to other relatively lower cost countries rather than effective policies, infrastructure, and technology to reduce world $\mathrm{CO}_{2} \mathrm{e}$. Therefore, consumption-based accounting is a good alternative for calculation carbon dioxide emissions [57]. Moreover, manufacturing products for European consumers in other countries possibly increases total GHG emissions due to longer transportation and unclean sources of energy.

Agglomeration and proximity analyses on the 16 lowest cost and $\mathrm{CO}_{2} \mathrm{e}$ supply chains are shown in Table 3. Fabric and garment manufacturing locations in the same countries, especially in Tunisia and Egypt, show high possibilities to achieve very low cost supply chains, while proximity among all supply chain stages in Europe helps achieve very low $\mathrm{CO}_{2}$ e supply chains.

Table 3. Cross-tabulation results of proximity and agglomeration between supply chain stages from the 16 lowest cost and $\mathrm{CO}_{2}$ e supply chains.

\begin{tabular}{|c|c|c|c|c|}
\hline $\begin{array}{c}\text { Proximity or } \\
\text { Agglomerated Stages }\end{array}$ & Cost, Country & Cost, Continent & $\mathrm{CO}_{2} \mathrm{e}$, Country & $\mathrm{CO}_{2} \mathrm{e}$, Continent \\
\hline Fiber and fabric & & EU (1) & AT (5) & EU (16) \\
\hline Fabric and garment & $\begin{array}{c}\mathrm{PL}(2), \mathrm{TN}(6), \mathrm{EG} \\
(6), \mathrm{TR}(2)\end{array}$ & $\mathrm{EU}(4), \mathrm{AF}(12)$ & $\begin{array}{c}\mathrm{AT}(1), \mathrm{DE}(1), \mathrm{IT} \\
(1)\end{array}$ & EU (16) \\
\hline Garment and warehouse & & EU (4) & $\mathrm{DE}(4)$ & EU (16) \\
\hline Fabric and firm & & EU (4) & DE (5) & EU (16) \\
\hline Garment and firm & & EU (4) & DE (4) & EU (16) \\
\hline
\end{tabular}

Remarks: Number in parenthesis refers to the number of supply chains out of the 16 lowest cost and carbon dioxide equivalent $\left(\mathrm{CO}_{2} \mathrm{e}\right)$ supply chains which have location proximity and agglomeration between stages; EU refers to Europe and other acronyms refer to Figure 5.

\subsection{Step 9: Supply Chain Selection}

Based on the objective, we plot all 1536 supply chains in a scatter plot between cost and $\mathrm{CO}_{2} \mathrm{e}$ to find optimized cost and $\mathrm{CO}_{2}$ e supply chains which are located on its Pareto frontier line, as shown in Figure A3 in Appendix C. The results show ten optimized supply chains, six of which have costs within the budget. Ultimately, we selected Poland and Austria for t-shirt/fabric production and fiber sourcing, respectively (AT-PL-PL), because this supply chain has the lowest $\mathrm{CO}_{2} \mathrm{e}$. Of note, five of the ten optimized supply chains have fiber, fabric, and garment manufacturing in Europe, while the other five supply chains have fabric and garment manufacturing in Africa with Austrian, US, and Indonesian fibers. This shows that the supply locations of the optimized supply chains are similar to the locations of very low cost and $\mathrm{CO}_{2} \mathrm{e}$ supply chains in terms of the proximity between fabric and garment manufacturing, and that their locations are in proximity to Germany. 
To ensure the selected supply chain can serve the future markets in China and America, we use cross-tabulation among Pareto-optimized supply chains of all three markets, as shown in Table 4. Table 4 shows that the selected AT-PL-PL supply chain exceeds the 10,000-euro budget when producing $1800 \mathrm{t}$-shirts to be delivered to the Chinese and US markets. Therefore, we select a new supply chain that uses Austrian fibers to produce fabrics and t-shirts in Egypt (AT-EG-EG) because this represents the lowest $\mathrm{CO}_{2}$ e optimized supply chain within budget.

Table 4. Pareto-optimized supply chains of three markets with costs and carbon dioxide equivalent $\left(\mathrm{CO}_{2} \mathrm{e}\right)$ for one 1800 -t-shirt batch.

\begin{tabular}{ccccccc}
\hline Supply Chain & $\mathbf{D E}, \boldsymbol{\epsilon}$ & $\mathbf{D E}, \mathbf{k g ~ C O} \mathbf{C O}_{\mathbf{2}} \mathbf{e}$ & $\mathbf{C N}, \boldsymbol{\epsilon}$ & $\mathbf{C N}, \mathbf{k g ~ \mathbf { C O } _ { \mathbf { 2 } } \mathbf { e }}$ & $\mathbf{U S}, \boldsymbol{\epsilon}$ & $\mathbf{U S}, \mathbf{k g ~ \mathbf { C O } _ { \mathbf { 2 } } \mathbf { e }}$ \\
\hline AT-AT-AT & 15,867 & 6122 & 20,494 & 6256 & 18,827 & 6288 \\
AT-AT-LT & 15,387 & 6438 & 19,010 & 6487 & 17,928 & 6596 \\
AT-IT-IT & 13,392 & 6548 & 17,313 & 6641 & 15,929 & 6694 \\
AT-LT-LT & 10,325 & 6616 & 13,176 & 6665 & 12,377 & 6774 \\
AT-PL-PL & 8685 & 7791 & 11,233 & 7882 & 10,540 & 7990 \\
AT-TR-TR & - & - & 10,989 & 8102 & 10,048 & 8119 \\
AT-TN-TN & 8572 & 8056 & 10,088 & 8133 & 9425 & 8177 \\
AT-EG-EG & 8215 & 8291 & 9871 & 8368 & 9030 & 8370 \\
US-TN-TN & 7921 & 10041 & 9253 & 10,117 & 8660 & 10162 \\
ID-EG-EG & 7777 & 10245 & - & - & 8515 & 10324 \\
US-EG-EG & 7768 & 10296 & - & - & 8505 & 10375 \\
\hline
\end{tabular}

Remarks: Supply chain name refers to its fiber-fabric-garment manufacturing locations; acronyms of locations refer to Figure 5.

\subsection{Step 10: Supply Chain Evaluation by Sensitivity and Scenario Analyses}

We perform sensitivity analysis as a validation procedure [31]. The application outcomes in terms of the lowest cost and $\mathrm{CO}_{2}$ e supply chains are robust when increasing or decreasing coefficient values of the following manufacturing factors by 25 percent: productivity, solid waste amounts, percentages of profits and factory overheads, and interest rates.

When changing coefficients of each cost factor in all locations or one location at a time by 25 percent, the lowest cost supply chain (US-EG-EG) is affected by changing values of fiber prices and transportation costs. The results show that fabric and garment manufacturing in Egypt will still be the best alternative location for achieving the lowest cost supply chain, but fibers would have to be sourced from Indonesia instead of America. Other fiber manufacturing locations aside from Great Britain will be fiber locations of the new lowest cost supply chain if their prices decrease. Furthermore, Tunisia will become the fabric and garment manufacturing location instead of Egypt after decreasing Tunisian operator wages, ship freight to Tunisia, or manager and transportation costs to visit factories in Tunisia, or after increasing ship freight to Egypt or manager and transportation costs to visit Egypt. Changes of the following factors do not change the lowest cost supply chain: truck fees, duty fees of fibers, fabrics, and garments from and to every location, indirect labor wages, wood prices for onsite energy, electricity fees, rent, solid waste management fees, certificate fees and implementation, sample delivery, lab test fees, and hotel costs during factory visits.

When changing coefficients of each $\mathrm{CO}_{2} \mathrm{e}$ factor at all locations or one location at a time, only increasing $\mathrm{CO}_{2} \mathrm{e}$ of factory-visiting flights to Austria or all locations at once changes the lowest $\mathrm{CO}_{2}$ e supply chain to have fabric and garment manufacturing in Germany instead of Austria. The lowest $\mathrm{CO}_{2} \mathrm{e}$ supply chain remains the same after changing values of the following factors by 25 percent: $\mathrm{CO}_{2}$, $\mathrm{CH}_{4}$, and $\mathrm{N}_{2} \mathrm{O}$ EFs of NRUE, $\mathrm{REU}$, solid waste landfill, truck vehicle, and ship vessels, and $\mathrm{CO}_{2} \mathrm{e}$ of sample delivery.

To see whether the selected optimized supply chain (AT-EG-EG) has high resistance to changing environments, we changed the coefficients of each manufacturing and cost factor relating to Austrian and Egyptian manufacturing, logistics, and sustainability assurance activities until the firm-scope cost of the supply chain exceeded the 10,000-euro budget. The results are in Table 5 and show that the selected supply chain has high resistance to all of the factor changes. 
Table 5. Resistance of the selected supply chain to changes of factor values by changing their coefficients until the supply chain cost exceed the 10,000-euro budget.

\begin{tabular}{|c|c|c|}
\hline Manufacturing Consumption Rate Coefficient & New Coefficient & Percent Change \\
\hline Fabric factory productivity (working time) & 0.28 & -72.36 \\
\hline Garment factory productivity (working time) & 0.12 & -88.19 \\
\hline Percentage of fabric factory overheads or profits & 6.51 & 550.56 \\
\hline Percentage of garment factory overheads or profits & 5.71 & 471.09 \\
\hline Interest rate for headquarter $(\mathrm{DE})$ & 40.03 & 3903.29 \\
\hline Fiber cost from Austria & 1.98 & 97.73 \\
\hline Helper/cleaner wage & 11.80 & 1080.14 \\
\hline Operator wage & 4.32 & 332.29 \\
\hline Manager wage & 4.06 & 305.81 \\
\hline Other administrative employee wage & 152.77 & $15,177.00$ \\
\hline Social security employer contribution & 7.66 & 666.49 \\
\hline Electricity rate & 19.45 & 1845.28 \\
\hline Woodchip price & 131.15 & $13,014.59$ \\
\hline Water rate & 55.63 & 5463.49 \\
\hline Solid waste management fee & 1225.64 & $122,464.42$ \\
\hline Rent & 5712.41 & $571,141.14$ \\
\hline Fabric employee certificate costs & 63.02 & 6202.14 \\
\hline Garment employee certificate costs & 136.47 & $13,547.09$ \\
\hline Fabric lab test fee & 20.65 & 1965.17 \\
\hline Fabric sample delivery cost & 107.02 & $10,601.84$ \\
\hline Garment sample delivery cost & 236.87 & $23,587.39$ \\
\hline Transportation cost for visiting a factory & 3.50 & 249.74 \\
\hline Manager cost for visiting a factory & 1.64 & 64.04 \\
\hline Hotel cost for visiting a factory & 41.32 & 4032.46 \\
\hline $\begin{array}{c}\text { Ship LCL (Less-than-Container-Load) price from } \\
\text { Austria and to Egypt }\end{array}$ & 3.68 & 268.01 \\
\hline Ship LCL price from Egypt & 4.94 & 393.93 \\
\hline
\end{tabular}

Remarks: Original coefficient values are 1; the selected supply chain has fiber manufacturing in Austria and fabric and garment manufacturing in Egypt; Cost factors from helper/cleaner wage to hotel cost for visiting fabric and garment factories relate to only Egypt; and duty fees of fibers, fabrics, and garments between Egypt and European countries are zero so changing coefficients of duty fees does not affect anything.

As mentioned in Step 8, different scenarios will be created by varying the number of manufacturing batches to see their effects on supply chain costs and $\mathrm{CO}_{2} \mathrm{e}$. Scatter plotting in Step 9B is used to find optimized supply chains of 6-, 12-, and 18-manufacturing batches that are compared by cross-tabulation as shown in Table 6 . High numbers of manufacturing batches allow costs of sustainability assurance activities to be allocated into several product units across the number of manufacturing batches leading to lower costs per batch. Table 6 shows that after increasing the number of batches to a certain level, per-batch cost and $\mathrm{CO}_{2} \mathrm{e}$ do not decrease significantly. Cost and $\mathrm{CO}_{2} \mathrm{e}$ of one-batch manufacturing are much higher than those of 6-, 12-, and 18-batch manufacturing. This demonstrates the importance of calculating cost and $\mathrm{CO}_{2} \mathrm{e}$ from sustainability assurance activities for products with low numbers of manufacturing units and batches per factory visit. Table 6 also shows that the more manufacturing batches, the more Pareto-optimized supply chains exist. There are six common optimized supply chains among 1-, 6-, 12-, and 18-manufacturing batches, and three of them have costs within budget. Out of the three, AT-EG-EG is the only one applicable to all three markets. This step confirms that the selected supply chain (AT-EG-EG) has high resistance to different markets and number of manufacturing batches. 
Table 6. Costs and carbon dioxide equivalent $\left(\mathrm{CO}_{2} \mathrm{e}\right)$ per one 1800-t-shirt batch for Pareto-optimized supply chains of 6-, 12-, and 18-manufacturing batches for the European market.

\begin{tabular}{|c|c|c|c|c|c|c|c|c|}
\hline \multirow[b]{2}{*}{ Supply Chain } & \multicolumn{2}{|c|}{1 Batch } & \multicolumn{2}{|c|}{6 Batches } & \multicolumn{2}{|c|}{12 Batches } & \multicolumn{2}{|c|}{18 Batches } \\
\hline & $€$ & $\mathrm{kgCO}_{2} \mathrm{e}$ & $€$ & $\mathrm{kgCO}_{2} \mathrm{e}$ & $€$ & $\mathrm{kgCO} 2 \mathrm{e}$ & $€$ & $\mathrm{kgCO} \mathrm{CO}_{2}$ \\
\hline AT-AT-AT & 15,867 & 6122 & 13,769 & 5527 & 13,559 & 5467 & 13,489 & 5447 \\
\hline AT-AT-LT & 15,387 & 6438 & 10,953 & 5695 & 10,509 & 5621 & 10,361 & 5596 \\
\hline AT-IT-IT & 13,392 & 6548 & & & & & & \\
\hline AT-LT-LT & 10,325 & 6616 & 7893 & 5725 & 7650 & 5636 & 7569 & 5606 \\
\hline AT-PL-PL & 8685 & 7791 & & & & & & \\
\hline AT-TN-LT & & & 7508 & 6114 & 6956 & 5989 & 6772 & 5948 \\
\hline AT-EG-LT & & & 7388 & 6139 & 6849 & 6002 & 6669 & 5956 \\
\hline AT-TN-TN & 8572 & 8056 & & & & & & \\
\hline AT-EG-EG & 8215 & 8291 & 5163 & 6448 & 4858 & 6264 & 4756 & 6203 \\
\hline US-TN-TN & 7921 & 10,041 & & & & & & \\
\hline AT-BD-BD & & & & & 4811 & 6971 & 4673 & 6826 \\
\hline${ }^{1}$ ID-EG-EG & 7777 & 10,245 & 4725 & 8403 & 4420 & 8218 & 4318 & 8157 \\
\hline${ }^{1}$ US-EG-EG & 7768 & 10,296 & 4716 & 8454 & 4411 & 8270 & 4309 & 8209 \\
\hline ID-BD-BD & & & & & 4374 & 8658 & 4235 & 8513 \\
\hline CN(N)-BD-BD & & & & & 4357 & 8736 & 4218 & 8590 \\
\hline ID-ID-ID & & & & & 4347 & 8820 & 4206 & 8620 \\
\hline
\end{tabular}

Remarks: These supply chains with different values are also Pareto-optimized supply chains of the Chinese and United States markets unless stated; ${ }^{1}$ they are not Pareto-optimized supply chains for the Chinese market; and acronyms of locations refer to Figure 5 .

\section{Conclusions, Contributions, Limitations, and Implications}

This paper proposes a strategic supply location decision-making (SLDM) approach for systematically analyzing and selecting multi-tier supply locations of a product supply chain, taking into consideration triple bottom line (TBL) sustainability and resistance to risk and changing environments. Its development is based on industrial practices and problems as well as literature relating to supply location decisions and network design, and cost and carbon dioxide equivalents $\left(\mathrm{CO}_{2} \mathrm{e}\right)$ modelling. Adopting key aspects from existing studies and expert opinions, as well as iteratively developing and applying the previous version of the approach in product supply chains, helps improve the SLDM approach and increase its validity and reliability. Following the ten steps of the approach for application in the viscose t-shirt supply chain allows us to find, within specified cost constraints, the lowest and optimized cost and $\mathrm{CO}_{2} \mathrm{e}$ supply chains for two different scenarios: first, with one supply chain that supplies all markets; and second, with separate supply chains for each market. Sensitivity and scenario analyses demonstrate the approach's capability in delivering robust and high-resistance outcomes to changing factor values and environments.

The application reveals that agglomerated fabric and garment manufacturing located in a relatively low-cost country in Africa in proximity to a German warehouse and headquarter helps achieve very low cost supply chains, while proximity among fiber, fabric, and garment manufacturing located in European countries, whose emission factors of consumed energy and electricity are low, helps achieve very low $\mathrm{CO}_{2}$ e supply chains. Fiber manufacturing technology highly influences supply chain $\mathrm{CO}_{2} \mathrm{e}$ while sustainability-assurance activities performed by focal firms highly influence supply chain costs especially of products with a low ratio of production units per factory visit by the focal firm. The application shows the potential and pragmatic validity of the approach for aiding users to choose a supply chain configuration which enhances positive impact and attempts to reduce negative impact on each TBL dimension of sustainability, based on users' cost and $\mathrm{CO}_{2} \mathrm{e}$ constraints and preferences, as well as organizational contexts.

\subsection{Research Contributions}

The application results show that the approach can deliver answers to both research questions on finding the lowest or optimized low cost and $\mathrm{CO}_{2} \mathrm{e}$ supply chains for different markets and their important cost and $\mathrm{CO}_{2} \mathrm{e}$ factors, including potential risks. By considering cost and $\mathrm{CO}_{2} \mathrm{e}$ from 
sustainability assurance activities that are overlooked by existing studies which calculated cost and $\mathrm{CO}_{2} \mathrm{e}$ in supply chains, our approach differentiates itself from the other cost and $\mathrm{CO}_{2} \mathrm{e}$ computation methods in the existing studies. Moreover, its application reveals that supply locations of the lowest cost and $\mathrm{CO}_{2}$ e supply chains are not the lowest wage location and the market for zero transportation $\mathrm{CO}_{2} \mathrm{e}$. This is because reduced costs of transportation, duty, and factory visits from geographical proximity between fabric and garment manufacturing locations and headquarters outweigh reduced labor costs at factories. Furthermore, sources of energy and electricity for manufacturing activities have more influence on supply chain $\mathrm{CO}_{2} \mathrm{e}$ than transportation activities. As such, this research contributes to the following:

1. Supply location and manufacturing decision literature and quantitative decision-making approaches, by proposing a comprehensive supply location decision-making approach with manageable numbers of objective measurement criteria that integrate cost and $\mathrm{CO}_{2} \mathrm{e}$ from all business, environmental, and socio-economic factors of sustainability, as there is a need to integrate environmental and social aspects into criteria of sustainable supplier selection with solvable problems [27].

2. Computations of cost and $\mathrm{CO}_{2} \mathrm{e}$ in supply chains for the purpose of comparing supply chains, locations, and products, by considering cost and $\mathrm{CO}_{2} \mathrm{e}$ from sustainability assurance activities performed by focal firms. These activities have significant influence on supply chain cost and $\mathrm{CO}_{2} \mathrm{e}$, especially for products requiring high degrees of control by the focal firms.

3. Sustainable supply chain management literature, by helping identify which cost and $\mathrm{CO}_{2} \mathrm{e}$ factors most significantly influence supply chain cost and $\mathrm{CO}_{2} \mathrm{e}$. Moreover, readers can identify which of the factors are location- or distance-dependent and thus cannot be improved by manufacturers and focal firms, implying limits to supply chain performance improvements. Manufactures and focal firms will have to rely on other stakeholders, such as governments and logistics providers, to improve the cost and $\mathrm{CO}_{2}$ e factors by means such as implementing clean sources of electricity and transportation technology to reduce transportation $\mathrm{CO}_{2} \mathrm{e}$.

\subsection{Research Limitations, Future Research Directions, and Practical Implications}

The limitation of the SLDM approach is that users have to know their manufacturing activities and related factors, as well as how to quantify cost and $\mathrm{CO}_{2} \mathrm{e}$ from them. They can learn these from the suggested factors and the pathways of each factor influencing costs and $\mathrm{CO}_{2} \mathrm{e}$ and each TBL dimension shown in this paper. Moreover, as the approach usually gives a set of low-cost and $\mathrm{CO}_{2} \mathrm{e}$ supply chains, users will need to know their cost and $\mathrm{CO}_{2} \mathrm{e}$ constraints and preferences to effectively choose a final supply chain. This implies that the chosen supply chain is not necessarily the most sustainable. However, most important is that the approach shows focal firms how much the cost of a product should be when it is manufactured with environmental and social compliance, and that they should be skeptical of low product prices quoted by suppliers if the price is much lower than the calculated cost from this approach, as the suppliers may squeeze their costs via environmental and social non-compliance.

Another limitation of this paper is that the application does not include socio-economic measurement criteria. As mentioned in the model formulation section and in the pathway figure, future research can measure human health impact from $\mathrm{CO}_{2} \mathrm{e}$ and contribution to gross domestic production at each supply stage. These measures will help link business, environmental, and socio-economic dimensions of sustainability. Furthermore, if users evaluate and compare existing supply chains, different supply chains and suppliers may have, for example, different manufacturing technologies, productivity, and difficulty in collaboration; therefore, due to the flexibility of the approach, users can adjust coefficients of manufacturing consumption among different locations and add extra relevant costs which are not suggested in this paper. Moreover, users may use our approach to find a set of low cost and $\mathrm{CO}_{2}$ e supply chains and select a final supply chain from them with qualitative criteria and approach. 
Another limitation is the difficulty of data collection, though this can be lowered by choosing only one or two main suppliers per each supply stage with a limited number of potential locations. Governments can help overcome the difficulty by having a database providing all cost and emission factor data, such as electricity emission factors, import taxes, and prices of industrial water, electricity, waste collection and treatment, in order to support research and practices on sustainable supply network design, potentially resulting in industrial and sustainability improvement.

The purpose of showing the model application is to demonstrate how to use the model with real data in practice, as well as the model's potential to reveal the lowest or optimized cost and $\mathrm{CO}_{2}$ e supply chains, their most important factors, and possible local and global risks that impact the lowest cost and $\mathrm{CO}_{2} \mathrm{e}$ supply chains. Readers should bear in mind that the results of the model application, such as the locations of the lowest cost and $\mathrm{CO}_{2} \mathrm{e}$ supply chains and the landed cost and $\mathrm{CO}_{2} \mathrm{e}$, cannot be generalized because they are specific to the settings of the application in terms of product type and material, sampled locations, manufacturing consumption, and focal firm organizational contexts which influence which activities and their factors to include into supply chain cost and $\mathrm{CO}_{2}$ e calculation. Additionally, future research may test the SLDM approach in other industries, production batch sizes, and locations in order to improve the approach and possibly find patterns of common results among different industries and locations.

The SLDM approach is useful to various groups of practitioners. It allows industrial practitioners to plan and design their supply chain locations with long-term perspectives on risk factors, expansion markets, and future products with different governance levels, manufacturing batches, manufacturing technology, and recycling programs. The approach helps users understand interconnections among supply chain stages, as well as factors, activities, and outcomes leading to supply chain visibility to improve operations of different activities towards TBL sustainability in supply chains. As the sensitivity and scenario analyses during the application demonstrate that some locations cannot compete with others even if their factor values are dramatically changed, policymakers can use the SLDM approach to strategically invest resources in the factors that potentially improve their location competitiveness in terms of cost and $\mathrm{CO}_{2} \mathrm{e}$. The approach can help policy makers to realize which location- and distance-dependent factors should be improved to support TBL sustainability.

Author Contributions: Conceptualization, validation and review, P.S., S.T. and X.Z.; methodology, investigation, writing, visualization, P.S.; formal analysis, P.S. and S.T.; resources, S.T.; funding acquisition, X.Z. All authors have read and agreed to the published version of the manuscript.

Funding: This research was funded by the European Commission (EACEA), grant number $n^{\circ} 2016-1353 / 001-001-E M J D$ for Edition 2016.

Conflicts of Interest: The authors declare no conflict of interest.

\section{Appendix A. Data Collection for the Viscose T-Shirt Application}

In the below tables, the data are from data sources, application assumption, and authors' calculation based on Appendix B.

Appendix A.1. Manufacturing Data

Table A1. Cradle-to-factory gate energy use for man-made cellulose fiber manufacturing.

\begin{tabular}{ccccccc}
\hline & Austria & $\begin{array}{c}\text { China } \\
\text { (Nanjing) }\end{array}$ & Indonesia & $\begin{array}{c}\text { Great } \\
\text { Britain }\end{array}$ & $\begin{array}{c}\text { The United } \\
\text { States }\end{array}$ & Thailand \\
\hline NREU, MJ/kg [49] & 19 & 61 & 61 & 61 & 61 & 61 \\
REU, MJ/kg [49] & 51 & 45 & 45 & 45 & 45 & 45 \\
Total NREU, MJ & 10,260 & 32,942 & 32,942 & 32,942 & 32,942 & 32,942 \\
Total REU, MJ & 27,541 & 24,301 & 24,301 & 24,301 & 24,301 & 24,301 \\
\hline
\end{tabular}

Remark: NREU = non-renewable energy use, REU = renewable energy use. 
Table A2. Biomass energy calorific value.

\begin{tabular}{cccc}
\hline Parameter & Unit & Input Data & Remarks \\
\hline $\begin{array}{c}\text { Calorific values of } \\
\text { fuel wood }\end{array}$ & $\mathrm{MJ} / \mathrm{kg}$ or TJ/Gg & 15.60 & $\begin{array}{c}\text { Excel Sheet Emission Factor } \\
\text { Tool March 2017 [44] }\end{array}$ \\
\hline
\end{tabular}

Table A3. Inputs and outputs of each process in fabric and garment manufacturing.

\begin{tabular}{|c|c|c|c|c|c|}
\hline Activity & Parameter & Unit & $\begin{array}{l}\text { Calculated } \\
\text { Data }\end{array}$ & $\begin{array}{l}\text { Referred } \\
\text { Data [48] }\end{array}$ & Remarks \\
\hline \multirow{3}{*}{$\begin{array}{l}\text { Thread spinning } \\
\text { process }\end{array}$} & Input: viscose fiber & $\mathrm{kg}$ & 540.02 & 1.22 & \multirow{3}{*}{$\begin{array}{l}\text { for electricity cost } \\
\text { and } \mathrm{CO}_{2} \mathrm{e}\end{array}$} \\
\hline & Electricity & kWh & 2.09 & 0.0047222 & \\
\hline & Output: viscose thread & $\mathrm{kg}$ & 442.64 & 1 & \\
\hline \multirow{6}{*}{$\begin{array}{l}\text { Knitting and } \\
\text { dyeing process }\end{array}$} & Input: viscose thread & $\mathrm{kg}$ & 442.64 & $10,886,216.88$ & \multirow{6}{*}{$\begin{array}{l}\text { for water cost, electricity } \\
\mathrm{CO}_{2} \mathrm{e} \text { in water waste } \\
\text { treatment } \\
\text { for electricity cost } \\
\text { and } \mathrm{CO}_{2} \mathrm{e} \\
\text { for wood cost and } \mathrm{CO}_{2} \mathrm{e} \\
\text { for landfill } \mathrm{CO}_{2} \mathrm{e}\end{array}$} \\
\hline & Water & $\mathrm{m}^{3}$ & 73.19 & $1,800,000$ & \\
\hline & Electricity & $\mathrm{kWh}$ & 6.41 & 157,600 & \\
\hline & Heat & $\mathrm{kWh}$ & 541.34 & $13,313,521.07$ & \\
\hline & Output: viscose knit & $\mathrm{kg}$ & 442.64 & $10,886,220$ & \\
\hline & Solid waste & $\mathrm{kg}$ & 97.38 & & \\
\hline \multirow{5}{*}{$\begin{array}{l}\text { Cutting and } \\
\text { sewing process }\end{array}$} & Input: viscose knit & $\mathrm{kg}$ & 442.64 & 1414 & \multirow{5}{*}{$\begin{array}{c}\text { for water cost and } \\
\text { electricity } \mathrm{CO}_{2} \mathrm{e} \text { in water } \\
\text { waste treatment } \\
\text { for electricity cost, } \mathrm{CO}_{2} \mathrm{e} \\
\text { for landfill } \mathrm{CO}_{2} \mathrm{e}\end{array}$} \\
\hline & Water & $\mathrm{m}^{3}$ & 0.16 & 0.52 & \\
\hline & Electricity & $\mathrm{kWh}$ & 624.52 & 1995 & \\
\hline & Output: viscose t-shirt & $\mathrm{kg}$ & 360.00 & 1150 & \\
\hline & Solid waste & $\mathrm{kg}$ & 82.64 & & \\
\hline
\end{tabular}

Table A4. Manufacturing working-time conversion.

\begin{tabular}{cccc}
\hline Parameter & Unit & Input Data & Remarks \\
\hline Factory working months/year & month & 12 & \\
Factory working days/month & day & 26 & for rent cost, solid waste cost, indirect labor cost, overheads \\
Number of hours per shift & hour & 8 & for rent cost, waste cost, indirect labor cost, overheads \\
Number of shifts per day & shift & 2 & for rent cost, solid waste cost, indirect labor cost, overheads \\
\hline
\end{tabular}

Table A5. Wastewater treatment electricity in fabric and garment manufacturing.

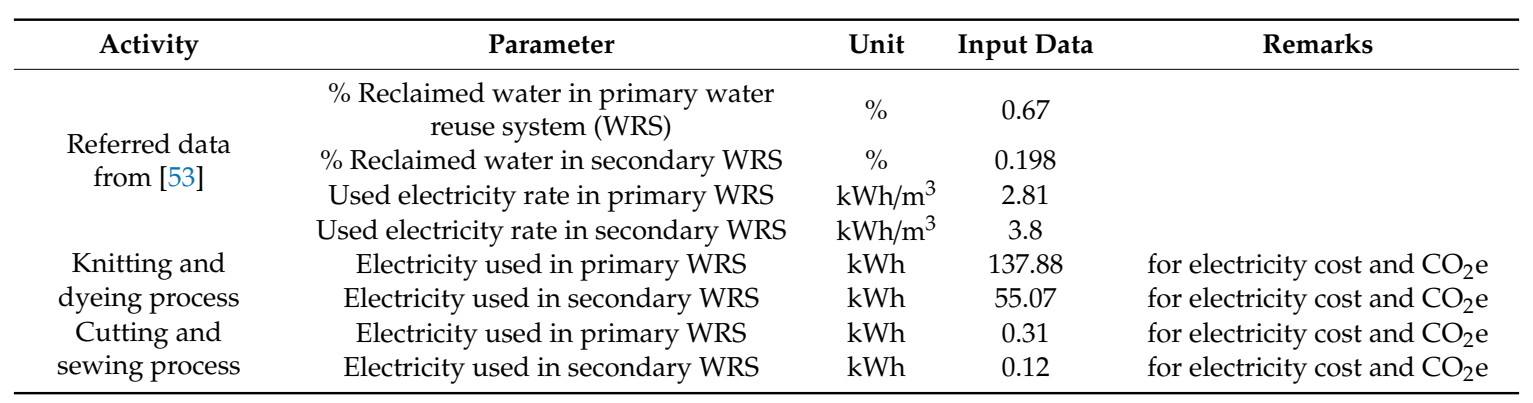

Table A6. Overheads electricity consumption in fabric and garment manufacturing.

\begin{tabular}{ccccc}
\hline Supply Stage & Parameter & Unit & Input Data & Remarks \\
\hline \multirow{2}{*}{ Referred data [58] } & Monthly energy for air conditioning & $\mathrm{kWh} / \mathrm{month}$ & 234,000 & \\
& Monthly energy for illuminating & $\mathrm{kWh} / \mathrm{month}$ & 43,200 & \\
& For total yarn production & $\mathrm{kg} / \mathrm{month}$ & 401,580 & \\
\multirow{2}{*}{ Fabric factory } & Required electricity for air conditioning & $\mathrm{kWh}$ & 257.93 & for electricity cost and $\mathrm{CO}_{2} \mathrm{e}$ \\
& Required electricity for illumination & $\mathrm{kWh}$ & 47.62 & for electricity cost and $\mathrm{CO}_{2} \mathrm{e}$ \\
Garment factory & Required electricity for air conditioning & $\mathrm{kWh}$ & 199.89 & for electricity cost and $\mathrm{CO}_{2} \mathrm{e}$ \\
& Required electricity for illumination & $\mathrm{kWh}$ & 36.903 & for electricity cost and $\mathrm{CO}_{2} \mathrm{e}$ \\
\hline
\end{tabular}


Table A7. Machine and direct labor in fabric and garment manufacturing.

\begin{tabular}{|c|c|c|c|c|}
\hline Activity & Parameter & Unit & Input Data & Remarks and Data Sources \\
\hline \multirow{3}{*}{$\begin{array}{l}\text { Thread } \\
\text { spinning } \\
\text { process }\end{array}$} & Machine capacity & $\mathrm{kg} / \mathrm{h}$ & 51.03 & [59] \\
\hline & Required machine operation time & $\mathrm{h}$ & 8.67 & \\
\hline & Direct labor required & person & 2 & \\
\hline \multirow{2}{*}{$\begin{array}{c}\text { Yarn dyeing } \\
\text { process }\end{array}$} & Package dyeing machine capacity & $\mathrm{kg} / \mathrm{h}$ & 42.50 & [50] \\
\hline & Required machine operation time & $\mathrm{h}$ & 10.42 & \\
\hline \multirow{5}{*}{$\begin{array}{l}\text { Fabric circular } \\
\text { knitting }\end{array}$} & Machine capacity, produced fabrics & $\mathrm{kg} / \mathrm{h}$ & 9.54 & [50] \\
\hline & Number of machines & machine & 2 & \\
\hline & Required machine operation time & $\mathrm{h}$ & 23.20 & for overhead costs \\
\hline & Direct labor required & person & 1 & \\
\hline & Required labor operation time & $\mathrm{h}$ & 23.20 & for labor cost (medium-skill wage) \\
\hline \multirow{4}{*}{ Cutting process } & Required fabric & yard & 1792.89 & \\
\hline & Required machine operation time & $\mathrm{h}$ & 9.16 & \\
\hline & Direct labor required & person & 1 & for labor cost (medium-skill wage) \\
\hline & Required labor operation time & $\mathrm{h}$ & 9.16 & for labor cost (medium-skill wage) \\
\hline \multirow{7}{*}{ Sewing process } & Operation minutes for a garment & minutes & 6.48 & [52] \\
\hline & Required machine operation time & $\mathrm{h}$ & 194.40 & \\
\hline & Total number of operators & person & 19 & [52], for labor cost (medium-skill wage) \\
\hline & Total number of helpers & person & 3 & [52], for labor cost (low-skill wage) \\
\hline & Required labor operation time & $\mathrm{h} /$ person & 10.23 & for overhead and labor cost \\
\hline & Total number of operators & person & 20 & for certificate implementation cost \\
\hline & Total number of helpers & person & 3 & for certificate implementation cost \\
\hline
\end{tabular}

Table A8. Rent and indirect labor in fabric and garment manufacturing.

\begin{tabular}{|c|c|c|c|c|}
\hline Supply Stage & Parameter & Unit & Input Data & Remarks \\
\hline \multirow{7}{*}{$\begin{array}{l}\text { Fabric factory } \\
\text { including spinning } \\
\text { and dyeing }\end{array}$} & Fabric factory size & $\mathrm{m}^{2}$ & 600 & \multirow{7}{*}{$\begin{array}{l}\text { for rent cost } \\
\text { for labor cost (highest high-skill } \\
\text { wage), certificate implementation cost } \\
\text { for labor cost (use medium/average } \\
\text { high-skill wage), certificate } \\
\text { implementation cost } \\
\text { for labor cost (low-skill wage), } \\
\text { employee training cost } \\
\text { depreciations and interest on capitals }\end{array}$} \\
\hline & Plant manager & person & 1 & \\
\hline & $\begin{array}{c}\text { Inspector, purchaser, sales, } \\
\text { HR }\end{array}$ & person & 4 & \\
\hline & Cleaners & person & 3 & \\
\hline & Other overheads & $\%$ & 10 & \\
\hline & Profit margin & $\%$ & 10 & \\
\hline & Total employees & person & 13 & \\
\hline \multirow{7}{*}{ Garment factory } & Garment factory size & $\mathrm{m}^{2}$ & 465 & \multirow{7}{*}{$\begin{array}{c}\text { for rent cost } \\
\text { for highest-skill labor cost, employee } \\
\text { training cost } \\
\text { for average-high skill labor cost, } \\
\text { employee training cost } \\
\text { for low-skill labor cost, employee } \\
\text { training cost } \\
\text { Depreciations and interest on capitals }\end{array}$} \\
\hline & Plant manager & person & 1 & \\
\hline & $\begin{array}{c}\text { Inspector, purchaser, sales, } \\
\text { HR }\end{array}$ & person & 4 & \\
\hline & Cleaners & person & 2 & \\
\hline & Other overheads & $\%$ & 10 & \\
\hline & Profit margin & $\%$ & 10 & \\
\hline & Total employees & person & 30 & \\
\hline
\end{tabular}


Appendix A.2. Cost Data

Appendix A.2.1. Manufacturing-Related Cost Data

Table A9. Prices and fees of fiber, electricity, woodchip, interest, and used garments.

\begin{tabular}{|c|c|c|c|c|c|}
\hline $\begin{array}{l}\text { Manufacturing } \\
\text { Locations }\end{array}$ & $\begin{array}{c}\text { Fiber Rate, } \\
€ / \mathbf{k g}\end{array}$ & $\begin{array}{l}\text { Industrial Electricity } \\
\text { rate, } € / \mathrm{kWh}\end{array}$ & $\begin{array}{l}\text { Woodchip } \\
\text { Rate, €/kg }\end{array}$ & $\begin{array}{c}\text { Interest Rate, } \\
\%\end{array}$ & $\begin{array}{l}\text { Used garment } \\
\text { Price, } € / \text { kg }\end{array}$ \\
\hline Austria & $2.29[60]$ & $0.10[61]$ & $0.06[62]$ & & \\
\hline China (Nanjing) & $1.69[60]$ & 0.10 [63] & 0.06 [62] & & $1.06[64]$ \\
\hline Indonesia & $1.77[60]$ & $0.07[65]$ & $0.07[62]$ & & \\
\hline Great Britain & $2.43[60]$ & 0.13 [61] & $0.02[62]$ & & \\
\hline USA & $1.22[60]$ & $0.06[66]$ & $0.07[62]$ & & $2.75[64]$ \\
\hline Thailand & $2.11[60]$ & $0.07[65]$ & $0.05[62]$ & & \\
\hline Germany & & $0.15[61]$ & 0.09 [62] & 1.93 [67] & $1.00[64]$ \\
\hline Italy & & 0.14 [61] & $0.10[62]$ & & \\
\hline Poland & & 0.09 [61] & $0.07[62]$ & & \\
\hline Lithuania & & $0.08[61]$ & $0.06[62]$ & & \\
\hline Tunisia & & $0.05[68]$ & $0.13[62]$ & & \\
\hline Egypt & & 0.05 [69] & $0.07[70]$ & & \\
\hline Turkey & & 0.06 [61] & 0.07 [62] & & \\
\hline China (Shanghai) & & 0.12 [63] & $0.06[62]$ & & \\
\hline Bangladesh & & 0.09 [71] & $0.10[62]$ & & \\
\hline India & & $0.06[72]$ & $0.05[73]$ & & \\
\hline
\end{tabular}

Table A10. Fees and prices of industrial water, solid waste management, and rent.

\begin{tabular}{|c|c|c|c|}
\hline $\begin{array}{c}\text { Manufacturing } \\
\text { Locations }\end{array}$ & $\begin{array}{c}\text { Industrial Water Rate, } \\
€ / \mathrm{m}^{3}\end{array}$ & $\begin{array}{c}\text { Solid Waste Fee }{ }^{1}, \\
€ / \text { year }\end{array}$ & $\begin{array}{l}\text { Rent Rate, } \\
\text { €/m²/Month }\end{array}$ \\
\hline Austria & $2.82[74]$ & 282.45 & $4.62[75]$ \\
\hline China (Nanjing) & $0.98[76]$ & 211.39 & 3.58 [77] \\
\hline Indonesia & $0.61[78]$ & 155.62 & $3.06[75]$ \\
\hline Great Britain & $4.60[74]$ & 282.45 & $3.72[79]$ \\
\hline USA & $0.90[74]$ & 282.45 & $5.05[80]$ \\
\hline Thailand & 0.68 [81] & 211.39 & $2.70[82]$ \\
\hline Germany & 4.13 [83] & 282.45 & $3.73[84]$ \\
\hline Italy & $0.74[74]$ & 282.45 & $4.75[85]$ \\
\hline Poland & $2.44[74]$ & 282.45 & 3.18 [86] \\
\hline Lithuania & $2.98[83]$ & 282.45 & $2.65[87]$ \\
\hline Tunisia & $0.54[88]$ & 155.62 & 0.98 [89] \\
\hline Egypt & 0.30 [90] & 155.62 & 2.78 [91] \\
\hline Turkey & 1.71 [92] & 211.39 & 2.42 [93] \\
\hline China (Shanghai) & $0.98[76]$ & 211.39 & 5.96 [77] \\
\hline Bangladesh & 0.37 [94] & 155.62 & 0.78 [95] \\
\hline India & 0.04 [96] & 155.62 & 1.59 [97] \\
\hline
\end{tabular}

Remarks: ${ }^{1}$ Based on three groups of solid waste management by country incomes, Table 5.5 in the What a Waste 2.0: A Global Snapshot of Solid Waste Management to 2050 book [98]. 
Table A11. Wages of helper/cleaner employees.

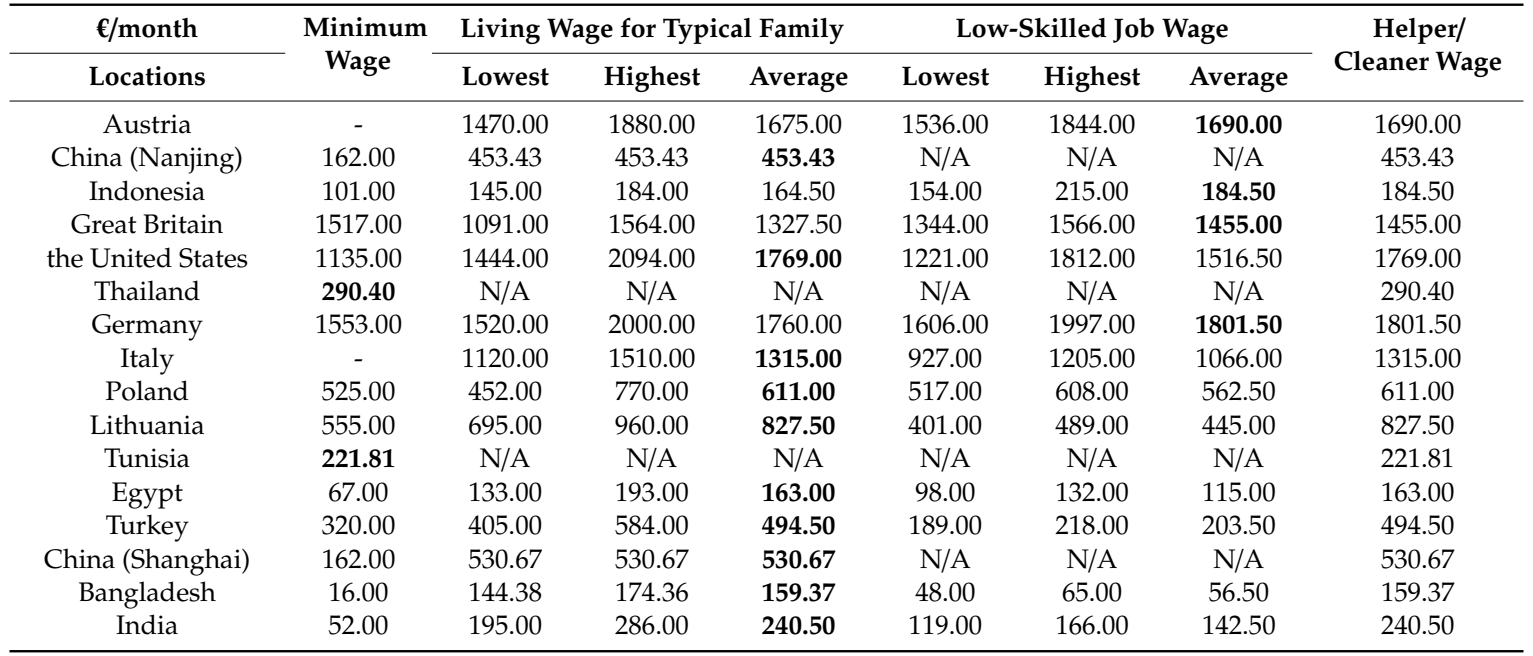

Remarks: Numbers in bold refer to where the helper/cleaner wages in the last column (to be used as inputs for calculating labor costs) come from; Minimum wages, the lowest and highest living wages, and the lowest and highest low-skilled job wages of all countries are from WageIndicator Foundation [99] excepting of Thailand and Tunisia whose minimum wages are from Minimum-Wage.org [100].

Table A12. Operator wage.

\begin{tabular}{ccccc}
\hline & \multicolumn{2}{c}{ Medium-Skilled Job Wage, $\mathbf{€}$ Month } & $\begin{array}{c}\text { Operator Wage, } \\
\text { Ł/Month }\end{array}$ \\
\cline { 2 - 4 } Locations & Lowest & Highest & Average & \\
\hline Austria & 2125.00 & 2639.00 & 2382.00 & 2382.00 \\
China (Nanjing) & 205.29 & 481.15 & 343.22 & 453.43 \\
Indonesia & 196.00 & 264.00 & 230.00 & 230.00 \\
Great Britain & 1718.00 & 2141.00 & 1929.50 & 1929.50 \\
the United States & $1,623.00$ & 2387.00 & 2005.00 & 2005.00 \\
Thailand & 382.79 & 395.87 & 389.33 & 389.33 \\
Germany & 2167.00 & 2826.00 & 2496.50 & 2496.50 \\
Italy & 1342.00 & 1678.00 & 1510.00 & 1510.00 \\
Poland & 665.00 & 836.00 & 750.50 & 750.50 \\
Lithuania & 513.00 & 655.00 & 584.00 & 827.50 \\
Tunisia & 222.04 & 265.93 & 243.98 & 243.98 \\
Egypt & 128.00 & 187.00 & 157.50 & 163.00 \\
Turkey & 206.00 & 263.00 & 234.50 & 494.50 \\
China (Shanghai) & 205.29 & 481.15 & 343.22 & 530.67 \\
Bangladesh & 50.00 & 76.00 & 63.00 & 159.37 \\
India & 180.00 & 282.00 & 231.00 & 240.50 \\
\hline
\end{tabular}

Remarks: Number in bolds refer to living wages in Table A11 because averaged medium-skill job wages of the countries are less than the living wages; The lowest and highest medium-skilled job wages of most countries are from WageIndicator Foundation [99] excepting the Chinese wages which are from a specific study of WageIndicator Foundation [101], the Thai wages which are from Trading Economics [102], the Tunisian wages which are from Numbeo [103]. 
Table A13. Plant managers' and other administrative employees' wages and employer social security contribution rate.

\begin{tabular}{|c|c|c|c|c|c|}
\hline \multirow{2}{*}{$\begin{array}{l}\text { €/Month } \\
\text { Locations }\end{array}$} & \multicolumn{2}{|c|}{ High-Skilled Job Wage ${ }^{2}$} & \multirow{2}{*}{$\begin{array}{l}\text { Average Wage of } \\
\text { Manager and Other } \\
\text { Position }\end{array}$} & \multirow{2}{*}{$\begin{array}{c}\text { Administrative } \\
\text { Employee } \\
\text { Wage }\end{array}$} & \multirow{2}{*}{$\begin{array}{c}\text { Social security } \\
\text { Contribution } \\
\text { [104], \% }\end{array}$} \\
\hline & Plant Manager ${ }^{1}$ & Other Position & & & \\
\hline China (Nanjing) & 3062.24 & 518.92 & 1790.58 & 1790.58 & 32.00 \\
\hline Indonesia & 2349.63 & 1870.39 & 2110.01 & 1870.39 & 9.74 \\
\hline Great Britain & 5747.87 & 5691.83 & 5719.85 & 5691.83 & 13.80 \\
\hline Thailand & 3469.81 & 1879.24 & 2674.52 & 1879.24 & 5.00 \\
\hline Germany & 7203.75 & 6621.42 & 6912.58 & 6621.42 & 19.83 \\
\hline Italy & 7004.17 & 6234.33 & 6619.25 & 6234.33 & 30.00 \\
\hline Poland & 3305.20 & 3305.20 & 3305.20 & 3305.20 & 21.00 \\
\hline Lithuania & 8142.08 & 892.92 & 4517.50 & 4517.50 & 1.77 \\
\hline Tunisia & 1859.46 & 142.74 & 1001.10 & 1001.10 & 16.57 \\
\hline Bangladesh & 1777.77 & 85.75 & 931.76 & 931.76 & 0.00 \\
\hline India & 1814.82 & 1471.84 & 1643.33 & 1471.84 & 12.00 \\
\hline
\end{tabular}

Remarks: ${ }^{1}$ Plant Manager and ${ }^{2}$ Other Position wages are from wages of 'manager' and of 'human resource and/or marketing managers' in 'career' tables appeared on the Average Salary Survey website [105], respectively. The data are based on at least 20 observations in order to be concurrent to wageindicator.org criteria. If the number of observations for each career does not reach 20 observations, the lowest and highest salaries from earning percentages, which are more than 20\%, are used; Plant Manager and Administrative Employee wages are used for calculating labor costs. Administrative Employee wages are from the Other Position wages excepting when the Other Position wages of some countries are much less than their Plant Manager wages, the average of Plant Manager and Other Position wages will be used. Bold numbers indicate the sources of Administrative Employee wages.

Table A14. Cost for certificate implementation.

\begin{tabular}{ccccc}
\hline $\begin{array}{c}\text { Maximum } \\
\text { Turnover, } \boldsymbol{\epsilon}\end{array}$ & Annual Turnover & $\begin{array}{c}\text { Certificate } \\
\text { Fee [106], } €\end{array}$ & $\begin{array}{c}\text { Auditing Fee [106], } \\
£\end{array}$ & $\begin{array}{c}\text { Total Fees for } \\
\text { Certificates and Audits } \\
\text { for Three Years, } \boldsymbol{\epsilon}\end{array}$ \\
\hline $117,146.00$ & Up to $£ 100,000$ & 995.00 & 450.00 & 1692.76 \\
$292,865.00$ & $£ 100,000-£ 250,000$ & $1,295.00$ & 500.00 & 2102.77 \\
$585,730.00$ & $£ 250,000-£ 500,000$ & $1,495.00$ & 550.00 & 2395.64 \\
$1,171,460.00$ & $£ 500,000-£ 1$ Million & $1,795.00$ & 600.00 & 2805.65 \\
$1,757,190.00$ & $£ 1-1.5$ Million & $1,995.00$ & 650.00 & 3098.51 \\
$2,342,920.00$ & $£ 1.5-2$ Million & $2,295.00$ & 700.00 & 3508.52 \\
$3,514,380.00$ & $£ 2-3$ Million & $2,795.00$ & 750.00 & 4152.83 \\
$5,857,300.00$ & $£ 3-5$ Million & $2,995.00$ & 850.00 & 4504.26 \\
\hline
\end{tabular}

Remarks: The certificate fee is valid for three years; learning time on sustainable practices for manager and other employees are 608 and $192 \mathrm{~h}$, respectively.

Table A15. Fabric testing fee with laboratory.

\begin{tabular}{cccccc}
\hline & $£$ & Min, $€$ & Max, $€$ & Average, $€$ & Reference \\
\hline Fabric testing & $45-60$ & 52.72 & 70.29 & 61.50 & {$[107]$} \\
\hline
\end{tabular}

Table A16. Cost and lead-time of sample delivery to laboratory and headquarters.

\begin{tabular}{ccccc}
\hline & $\begin{array}{c}\text { Fabric XS,600 } \\
\text { g, } \mathbf{f} / \text { pack with } \\
\text { Signature [108] }\end{array}$ & $\begin{array}{c}\text { Garment S, 1 kg, } \\
\boldsymbol{€} / \text { pack with } \\
\text { signature [108] }\end{array}$ & $\begin{array}{c}\text { Lead-Time, } \\
\text { Europe, Day } \\
\text { [109] }\end{array}$ & $\begin{array}{c}\text { Lead-Time, } \\
\text { Others, Day } \\
\text { [109] }\end{array}$ \\
\hline $\begin{array}{c}\text { Sample delivery cost/time } \\
\text { Number of sample deliveries }\end{array}$ & 5.70 & 6.20 & 2.00 & 7.50 \\
\hline
\end{tabular}


Appendix A.2.2. Firm's Sustainability Assurance Cost Data

Table A17. Firm's costs and time for sustainability assurance activities.

\begin{tabular}{cccccccc}
\hline & $\begin{array}{c}\text { Flight from } \\
\text { Dusseldorf } \\
\text { Airport, } \boldsymbol{\epsilon} \\
\text { [110] }\end{array}$ & $\begin{array}{c}\text { Domestic } \\
\text { Travel Costs, } \boldsymbol{\epsilon} \\
\text { (Taxi or Rental } \\
\text { Car) [111] }\end{array}$ & $\begin{array}{c}\text { Fuel Costs } \\
\text { for Rental } \\
\text { Car, } \boldsymbol{\epsilon} \\
\text { [112] }\end{array}$ & $\begin{array}{c}\text { Total Trip } \\
\text { Time, } \\
\text { Days }\end{array}$ & $\begin{array}{c}\text { Hotel } \\
\text { Cost [113] }\end{array}$ & $\begin{array}{c}\text { Number } \\
\text { of Car } \\
\text { Rental } \\
\text { Days }\end{array}$ & $\begin{array}{c}\text { Number } \\
\text { Hotel } \\
\text { Night }\end{array}$ \\
\hline $\begin{array}{c}\text { Austria } \\
\text { China (Nanjing) }\end{array}$ & 299.62 & 153.78 & 20.00 & 3 & 144.00 & 3 & 2 \\
Indonesia & 1762.64 & 42.00 & & 6 & 122.00 & 4 & 3 \\
Great Britain & 1259.24 & 80.00 & & 6 & 140.00 & 4 & 3 \\
USA & 485.75 & 63.87 & 8.00 & 4 & 217.00 & 4 & 3 \\
Thailand & 1650.65 & 221.27 & 38.00 & 6 & 139.00 & 4 & 3 \\
Germany & 1056.73 & 80.00 & & 5 & 93.00 & 4 & 3 \\
Italy & - & 110.00 & - & 3 & - & - & - \\
Poland & 269.05 & 49.58 & 6.00 & 3 & 97.00 & 3 & 2 \\
Lithuania & 237.84 & 72.06 & 38.00 & 3 & 50.00 & 3 & 2 \\
Tunisia & 357.75 & 10.00 & & 4 & 94.00 & 4 & 3 \\
Egypt & 698.94 & 24.00 & & 5 & 76.00 & 4 & 3 \\
Turkey & 576.45 & 24.00 & & 5 & 44.00 & 4 & 3 \\
China (Shanghai) & 335.88 & 40.00 & & 4 & 53.00 & 4 & 3 \\
Bangladesh & 904.78 & 50.00 & & 6 & 167.00 & 4 & 3 \\
India & 1292.11 & 12.00 & & 6 & 102.00 & 4 & 3 \\
\hline
\end{tabular}

\section{Appendix A.2.3. Logistics-Related Cost Data}

We searched logistics costs from the websites Searates.com [114] and Worldfreightrates.com [115] and freight insurance from the website Freightinsurancecenter.com [116]. Ship and truck insurance rates are 0.87 and 0.55 euro for every 100 euro of free on-board value of insured goods, with a minimum fee of 45 euros. Import duties were retrieved from the website simplyduty.com [117]. Number 1-16 in Tables A18-A22 refer to manufacturing locations in Austria, China (Nanjing), Indonesia, Great Britain, the United States, Thailand, Germany, Italy, Poland, Lithuania, Tunisia, Egypt, Turkey, China (Shanghai), Bangladesh, and India, respectively.

Table A18. Costs of transportation by truck and ship among the 16 manufacturing locations.

\begin{tabular}{cccccccccccccccccc}
\hline From/to & $\mathbf{1}$ & $\mathbf{2}$ & $\mathbf{3}$ & $\mathbf{4}$ & $\mathbf{5}$ & $\mathbf{6}$ & $\mathbf{7}$ & $\mathbf{8}$ & $\mathbf{9}$ & $\mathbf{1 0}$ & $\mathbf{1 1}$ & $\mathbf{1 2}$ & $\mathbf{1 3}$ & $\mathbf{1 4}$ & $\mathbf{1 5}$ & $\mathbf{1 6}$ & to \\
\hline $\mathbf{1}$ & 0 & 451 & 451 & 451 & 585 & 451 & $\mathbf{0 . 0 6}$ & $\mathbf{0 . 0 5}$ & $\mathbf{0 . 0 7}$ & $\mathbf{0 . 1 1}$ & 451 & 451 & 451 & 451 & 451 & 451 & 0.03 \\
$\mathbf{2}$ & 567 & 0 & 451 & 458 & 647 & 451 & 464 & 451 & 451 & 451 & 451 & 624 & 583 & $\mathbf{0 . 0 1}$ & 480 & 451 & 0.01 \\
$\mathbf{3}$ & 451 & 451 & 0 & 451 & 738 & 451 & 451 & 451 & 451 & 451 & 451 & 451 & 451 & 451 & 451 & 451 & 0.00 \\
$\mathbf{4}$ & 451 & 552 & 451 & 0 & 504 & 451 & 451 & 451 & 451 & 451 & 451 & 451 & 451 & 552 & 716 & 582 & 0.00 \\
$\mathbf{5}$ & 665 & 734 & 917 & 459 & 0 & 934 & 451 & 594 & 503 & 523 & 594 & 733 & 683 & 734 & 1246 & 1006 & 0.02 \\
$\mathbf{6}$ & 451 & 451 & 451 & 451 & 752 & 0 & 451 & 451 & 451 & 451 & 451 & 451 & 451 & 451 & 451 & 451 & 0.01 \\
$\mathbf{7}$ & $\mathbf{0 . 0 6}$ & 542 & 451 & 451 & 495 & 451 & 0 & $\mathbf{0 . 0 7}$ & $\mathbf{0 . 0 8}$ & $\mathbf{0 . 1 2}$ & 451 & 451 & 451 & 542 & 702 & 571 & 0.02 \\
$\mathbf{8}$ & $\mathbf{0 . 0 5}$ & 451 & 451 & 451 & 558 & 451 & $\mathbf{0 . 0 7}$ & 0 & $\mathbf{0 . 1 1}$ & $\mathbf{0 . 1 6}$ & 451 & 451 & 451 & 451 & 501 & 571 & 0.02 \\
$\mathbf{9}$ & $\mathbf{0 . 0 7}$ & 597 & 451 & 451 & 547 & 451 & $\mathbf{0 . 0 8}$ & $\mathbf{0 . 1 1}$ & 0 & $\mathbf{0 . 0 5}$ & 451 & 451 & 451 & 597 & 612 & 506 & 0.03 \\
$\mathbf{1 0}$ & $\mathbf{0 . 1 1}$ & 620 & 451 & 451 & 568 & 451 & $\mathbf{0 . 1 2}$ & $\mathbf{0 . 1 6}$ & $\mathbf{0 . 0 5}$ & 0 & 451 & 463 & 451 & 620 & 636 & 526 & 0.02 \\
$\mathbf{1 1}$ & 451 & 451 & 451 & 451 & 558 & 451 & 451 & 451 & 451 & 451 & 0 & 451 & 451 & 451 & 501 & 451 & 0.03 \\
$\mathbf{1 2}$ & 451 & 451 & 451 & 451 & 711 & 451 & 451 & 451 & 451 & 451 & 451 & 0 & 451 & 451 & 482 & 451 & 0.02 \\
$\mathbf{1 3}$ & 451 & 451 & 451 & 451 & 663 & 451 & 451 & 451 & 451 & 451 & 451 & 451 & 0 & 451 & 451 & 451 & 0.00 \\
$\mathbf{1 4}$ & 567 & $\mathbf{0 . 0 1}$ & 451 & 458 & 647 & 451 & 464 & 451 & 451 & 451 & 451 & 624 & 583 & 0 & 480 & 451 & 0.00 \\
$\mathbf{1 5}$ & 451 & 451 & 451 & 548 & 726 & 451 & 538 & 451 & 466 & 484 & 451 & 451 & 451 & 451 & 0 & 451 & 0.02 \\
$\mathbf{1 6}$ & 451 & 451 & 451 & 518 & 687 & 451 & 509 & 451 & 451 & 457 & 451 & 451 & 451 & 451 & 451 & 0 & 0.02 \\
from & 0.03 & 0.01 & 0.00 & 0.00 & 0.02 & 0.01 & 0.02 & 0.01 & 0.03 & 0.02 & 0.03 & 0.02 & 0.00 & 0.00 & 0.01 & 0.02 & \\
\hline
\end{tabular}

Remarks: Bold refers to truck cost in euro per kilogram and the rest is ship transportation price per ton in euro for the less-than-container load; the last column and row refer to truck cost in euro per kg to/from a port from/to a factory, respectively. 
Table A19. Import duty percentage for used garments (HS code 63090000).

\begin{tabular}{ccccccccccccccccc}
\hline From/To & $\mathbf{1}$ & $\mathbf{2}$ & $\mathbf{3}$ & $\mathbf{4}$ & $\mathbf{5}$ & $\mathbf{6}$ & $\mathbf{7}$ & $\mathbf{8}$ & $\mathbf{9}$ & $\mathbf{1 0}$ & $\mathbf{1 1}$ & $\mathbf{1 2}$ & $\mathbf{1 3}$ & $\mathbf{1 4}$ & $\mathbf{1 5}$ & $\mathbf{1 6}$ \\
\hline $\mathbf{1}$ & 0 & 0 & 0 & 0 & 0 & 0 & 0 & 0 & 0 & 0 & 0 & 0 & 0 & 0 & 0 & 0 \\
$\mathbf{2}$ & 5.3 & 0 & 0 & 5.3 & 0 & 30 & 5.3 & 5.3 & 5.3 & 5.3 & 20 & 35 & 0 & 0 & 0 & 25 \\
$\mathbf{3}$ & 0 & 0 & 0 & 0 & 0 & 0 & 0 & 0 & 0 & 0 & 0 & 0 & 0 & 0 & 0 & 0 \\
$\mathbf{4}$ & 0 & 0 & 0 & 0 & 0 & 0 & 0 & 0 & 0 & 0 & 0 & 0 & 0 & 0 & 0 & 0 \\
$\mathbf{5}$ & 5.3 & 14 & 35 & 5.3 & 0 & 30 & 5.3 & 5.3 & 5.3 & 5.3 & 20 & 35 & 5.3 & 14 & 0 & 25 \\
$\mathbf{6}$ & 0 & 0 & 0 & 0 & 0 & 0 & 0 & 0 & 0 & 0 & 0 & 0 & 0 & 0 & 0 & 0 \\
$\mathbf{7}$ & 0 & 14 & 35 & 0 & 0 & 30 & 0 & 0 & 0 & 0 & 20 & 0 & 0 & 14 & 0 & 25 \\
$\mathbf{8}$ & 0 & 0 & 0 & 0 & 0 & 0 & 0 & 0 & 0 & 0 & 0 & 0 & 0 & 0 & 0 & 0 \\
$\mathbf{9}$ & 0 & 0 & 0 & 0 & 0 & 0 & 0 & 0 & 0 & 0 & 0 & 0 & 0 & 0 & 0 & 0 \\
$\mathbf{1 0}$ & 0 & 0 & 0 & 0 & 0 & 0 & 0 & 0 & 0 & 0 & 0 & 0 & 0 & 0 & 0 & 0 \\
$\mathbf{1 1}$ & 0 & 0 & 0 & 0 & 0 & 0 & 0 & 0 & 0 & 0 & 0 & 0 & 0 & 0 & 0 & 0 \\
$\mathbf{1 2}$ & 0 & 0 & 0 & 0 & 0 & 0 & 0 & 0 & 0 & 0 & 0 & 0 & 0 & 0 & 0 & 0 \\
$\mathbf{1 3}$ & 0 & 0 & 0 & 0 & 0 & 0 & 0 & 0 & 0 & 0 & 0 & 0 & 0 & 0 & 0 & 0 \\
$\mathbf{1 4}$ & 5.3 & 0 & 0 & 5.3 & 0 & 30 & 5.3 & 5.3 & 5.3 & 5.3 & 20 & 35 & 0 & 0 & 0 & 25 \\
$\mathbf{1 5}$ & 0 & 0 & 0 & 0 & 0 & 0 & 0 & 0 & 0 & 0 & 0 & 0 & 0 & 0 & 0 & 0 \\
$\mathbf{1 6}$ & 0 & 0 & 0 & 0 & 0 & 0 & 0 & 0 & 0 & 0 & 0 & 0 & 0 & 0 & 0 & 0 \\
\hline
\end{tabular}

Table A20. Import duty percentage for viscose t-shirts (HS code 6114300000).

\begin{tabular}{ccccccccccccccccc}
\hline From/To & $\mathbf{1}$ & $\mathbf{2}$ & $\mathbf{3}$ & $\mathbf{4}$ & $\mathbf{5}$ & $\mathbf{6}$ & $\mathbf{7}$ & $\mathbf{8}$ & $\mathbf{9}$ & $\mathbf{1 0}$ & $\mathbf{1 1}$ & $\mathbf{1 2}$ & $\mathbf{1 3}$ & $\mathbf{1 4}$ & $\mathbf{1 5}$ & $\mathbf{1 6}$ \\
\hline $\mathbf{1}$ & 0 & 18 & 0 & 0 & 28 & 0 & 0 & 0 & 0 & 0 & 0 & 0 & 0 & 18 & 0 & 0 \\
$\mathbf{2}$ & 12 & 0 & 0 & 12 & 28 & 0 & 12 & 12 & 12 & 12 & 0 & 0 & 12 & 0 & 0 & 0 \\
$\mathbf{3}$ & 9.6 & 0 & 0 & 9.6 & 28 & 0 & 9.6 & 9.6 & 9.6 & 9.6 & 0 & 0 & 9.6 & 0 & 0 & 0 \\
$\mathbf{4}$ & 0 & 18 & 0 & 0 & 28 & 0 & 0 & 0 & 0 & 0 & 0 & 0 & 0 & 18 & 0 & 0 \\
$\mathbf{5}$ & 12 & 18 & 0 & 12 & 0 & 0 & 12 & 12 & 12 & 12 & 0 & 0 & 12 & 18 & 0 & 0 \\
$\mathbf{6}$ & 12 & 0 & 0 & 12 & 28 & 0 & 12 & 12 & 12 & 12 & 0 & 0 & 12 & 0 & 0 & 0 \\
$\mathbf{7}$ & 0 & 18 & 0 & 0 & 28 & 0 & 0 & 0 & 0 & 0 & 0 & 0 & 0 & 18 & 0 & 0 \\
$\mathbf{8}$ & 0 & 18 & 0 & 0 & 28 & 0 & 0 & 0 & 0 & 0 & 0 & 0 & 0 & 18 & 0 & 0 \\
$\mathbf{9}$ & 0 & 18 & 0 & 0 & 28 & 0 & 0 & 0 & 0 & 0 & 0 & 0 & 0 & 18 & 0 & 0 \\
$\mathbf{1 0}$ & 0 & 18 & 0 & 0 & 28 & 0 & 0 & 0 & 0 & 0 & 0 & 0 & 0 & 18 & 0 & 0 \\
$\mathbf{1 1}$ & 0 & 18 & 0 & 0 & 28 & 0 & 0 & 0 & 0 & 0 & 0 & 0 & 0 & 18 & 0 & 0 \\
$\mathbf{1 2}$ & 0 & 18 & 0 & 0 & 28 & 0 & 0 & 0 & 0 & 0 & 0 & 0 & 0 & 18 & 0 & 0 \\
$\mathbf{1 3}$ & 0 & 18 & 0 & 0 & 28 & 0 & 0 & 0 & 0 & 0 & 0 & 0 & 0 & 18 & 0 & 0 \\
$\mathbf{1 4}$ & 12 & 0 & 0 & 12 & 28 & 0 & 12 & 12 & 12 & 12 & 0 & 0 & 12 & 0 & 0 & 0 \\
$\mathbf{1 5}$ & 0 & 18 & 0 & 0 & 28 & 0 & 0 & 0 & 0 & 0 & 0 & 0 & 0 & 18 & 0 & 0 \\
$\mathbf{1 6}$ & 9.6 & 18 & 0 & 9.6 & 28 & 0 & 9.6 & 9.6 & 9.6 & 9.6 & 0 & 0 & 9.6 & 18 & 0 & 0 \\
\hline
\end{tabular}

Table A21. Import duty percentage for viscose fabrics (HS code 6006320000).

\begin{tabular}{ccccccccccccccccc}
\hline From/To & $\mathbf{1}$ & $\mathbf{2}$ & $\mathbf{3}$ & $\mathbf{4}$ & $\mathbf{5}$ & $\mathbf{6}$ & $\mathbf{7}$ & $\mathbf{8}$ & $\mathbf{9}$ & $\mathbf{1 0}$ & $\mathbf{1 1}$ & $\mathbf{1 2}$ & $\mathbf{1 3}$ & $\mathbf{1 4}$ & $\mathbf{1 5}$ & $\mathbf{1 6}$ \\
\hline $\mathbf{1}$ & 0 & 10 & 10 & 0 & 10 & 0 & 0 & 0 & 0 & 0 & 20 & 0 & 0 & 10 & 0 & 25 \\
$\mathbf{2}$ & 8 & 0 & 0 & 8 & 10 & 0 & 8 & 8 & 8 & 8 & 20 & 10 & 0 & 0 & 0 & 25 \\
$\mathbf{3}$ & 0 & 0 & 0 & 0 & 10 & 0 & 0 & 0 & 0 & 0 & 20 & 10 & 0 & 0 & 0 & 25 \\
$\mathbf{4}$ & 0 & 0 & 0 & 0 & 10 & 0 & 0 & 0 & 0 & 0 & 20 & 0 & 0 & 10 & 0 & 25 \\
$\mathbf{5}$ & 8 & 10 & 10 & 8 & 0 & 0 & 8 & 8 & 8 & 8 & 20 & 10 & 8 & 10 & 0 & 25 \\
$\mathbf{6}$ & 8 & 0 & 0 & 8 & 10 & 0 & 8 & 8 & 8 & 8 & 20 & 10 & 0 & 0 & 0 & 25 \\
$\mathbf{7}$ & 0 & 10 & 10 & 0 & 10 & 0 & 0 & 0 & 0 & 0 & 20 & 0 & 0 & 10 & 0 & 25 \\
$\mathbf{8}$ & 0 & 10 & 10 & 0 & 10 & 0 & 0 & 0 & 0 & 0 & 20 & 0 & 0 & 10 & 0 & 25 \\
$\mathbf{9}$ & 0 & 10 & 10 & 0 & 10 & 0 & 0 & 0 & 0 & 0 & 20 & 0 & 0 & 10 & 0 & 25 \\
$\mathbf{1 0}$ & 0 & 10 & 10 & 0 & 10 & 0 & 0 & 0 & 0 & 0 & 20 & 0 & 0 & 10 & 0 & 25 \\
$\mathbf{1 1}$ & 0 & 10 & 10 & 0 & 10 & 0 & 0 & 0 & 0 & 0 & 0 & 0 & 0 & 10 & 0 & 25 \\
$\mathbf{1 2}$ & 0 & 10 & 10 & 0 & 10 & 0 & 0 & 0 & 0 & 0 & 20 & 0 & 0 & 10 & 0 & 25 \\
$\mathbf{1 3}$ & 0 & 10 & 10 & 0 & 10 & 0 & 0 & 0 & 0 & 0 & 20 & 0 & 0 & 10 & 0 & 25 \\
$\mathbf{1 4}$ & 8 & 0 & 0 & 8 & 10 & 0 & 8 & 8 & 8 & 8 & 20 & 10 & 0 & 0 & 0 & 25 \\
$\mathbf{1 5}$ & 0 & 0 & 0 & 0 & 10 & 0 & 0 & 0 & 0 & 0 & 20 & 10 & 0 & 0 & 0 & 25 \\
$\mathbf{1 6}$ & 0 & 8.5 & 8.3 & 8 & 10 & 0 & 0 & 0 & 0 & 0 & 20 & 10 & 0 & 8.5 & 0 & 0 \\
\hline
\end{tabular}


Table A22. Import duty percentage for viscose fiber staplers (HS code 5504100000).

\begin{tabular}{ccccccccccccccccc}
\hline From/to & $\mathbf{1}$ & $\mathbf{2}$ & $\mathbf{3}$ & $\mathbf{4}$ & $\mathbf{5}$ & $\mathbf{6}$ & $\mathbf{7}$ & $\mathbf{8}$ & $\mathbf{9}$ & $\mathbf{1 0}$ & $\mathbf{1 1}$ & $\mathbf{1 2}$ & $\mathbf{1 3}$ & $\mathbf{1 4}$ & $\mathbf{1 5}$ & $\mathbf{1 6}$ \\
\hline $\mathbf{1}$ & 0 & 5 & 5 & 0 & 4.3 & 0 & 0 & 0 & 0 & 0 & 0 & 0 & 0 & 5 & 0 & 20 \\
$\mathbf{2}$ & 4 & 0 & 0 & 4 & 4.3 & 0 & 4 & 4 & 4 & 4 & 0 & 0 & 4 & 0 & 0 & 20 \\
$\mathbf{3}$ & 0 & 0 & 0 & 0 & 4.3 & 0 & 0 & 0 & 0 & 0 & 0 & 0 & 0 & 0 & 0 & 20 \\
$\mathbf{4}$ & 0 & 0 & 5 & 0 & 4.3 & 0 & 0 & 0 & 0 & 0 & 0 & 0 & 0 & 5 & 0 & 20 \\
$\mathbf{5}$ & 4 & 5 & 5 & 4 & 0 & 0 & 4 & 4 & 4 & 4 & 0 & 0 & 4 & 5 & 0 & 20 \\
$\mathbf{6}$ & 4 & 0 & 0 & 4 & 4.3 & 0 & 4 & 4 & 4 & 4 & 0 & 0 & 4 & 0 & 0 & 20 \\
\hline
\end{tabular}

\section{Appendix B. Cost and Carbon Dioxide Equivalent (CO2e) Computations for the Viscose T-Shirt Application}

\section{Appendix B.1. Manufacturing Cost and CO2e Computations}

Manufacturing costs in each supply stage $\left(\operatorname{cost}_{\mathrm{M}}\right)$ are calculated by summing the results of Equations (A1)-(A14), the other overhead costs, and profits. Recycling costs can be calculated with the same equations. All input and output amounts and time shown in the equations are for one-batch manufacturing. Unspecified acronyms refer to factors in Figure 2 shown in the paper. The materials cost of the initial stage (d) can be calculated by Equation (A1a). If the cost rate ${ }_{\mathrm{Mi}}$ for inputs of the initial stage (d) is the Ex Works (EXW) price at the factory at the earlier stage (d-1), logistics costs from d- 1 to $\mathrm{d}$ location has to be included. Material cost $\mathrm{Mi}$ of subsequent stages ( $\mathrm{c}$ and $\mathrm{b}$ ) is calculated from the summation of manufacturing costs of the previous stage ( $\mathrm{d}$ or $\mathrm{c}$ ) with logistics costs (from $\mathrm{d}$ to $\mathrm{c}$ or $\mathrm{c}$ to b), as shown in Equation (A1b).

$$
\begin{gathered}
\text { Material cost } \mathrm{Mi}_{\mathrm{d}}=\text { Amount }_{\mathrm{Mi}} \times \text { Cost rate }_{\mathrm{Mi}} \\
\text { Material } \operatorname{cost}_{\mathrm{Mi}} \text { for c or b }=\operatorname{Cost}_{\mathrm{M} \text { at d or c }}+\operatorname{Cost}_{\mathrm{L}, \mathrm{d} \text { to c or c to } \mathrm{b}}
\end{gathered}
$$

Direct and indirect employee costs are calculated according to Equations (A2)-(A4).

$$
\text { Direct labor } \operatorname{cost}_{\mathrm{Mhd}}=\mathrm{Mt} \times \text { Number of people } \mathrm{Mhh}_{\mathrm{M}} \times \text { Hourly wage } \mathrm{Mhd}_{\mathrm{M}}
$$

Indirect labor $\operatorname{cost}_{\mathrm{Mhi}}=\left(\right.$ Mt or $\left.\mathrm{T}_{\mathrm{B}}\right) \times$ Number of people $_{\mathrm{Mhi}} \times$ Hourly wage $_{\text {Mhi }}$

Administrative employee $\operatorname{cost}_{\mathrm{Mha}}=\mathrm{T}_{\mathrm{B}} \times$ Number of people $\mathrm{Mha}_{\mathrm{a}} \times$ Hourly wage $\mathrm{e}_{\mathrm{Mh}}$

where $T_{B}$ refers to total factory-working time of each batch. Hourly wage refers to industrial wages or occupational wages for workers and positions of different skill levels. The wages have to be equal to or higher than the living wage of each location. If not, living wages should be used in order to ensure human rights, social equality, and socio-economic sustainability.

Costs of water, electricity, and onsite heating can be calculated by Equations (A5)-(A7)

$$
\text { Water } \operatorname{cost}_{\mathrm{Mw}}=\text { Amount }_{\mathrm{Mw}} \times \text { Cost rate }_{\mathrm{Mw}}
$$

$$
\text { Electricity cost }=\text { Amount }_{(\mathrm{Mep}+\mathrm{Mew}+\mathrm{Meo})} \times \text { Electricity cost rate }
$$

Heat $\operatorname{cost}_{\mathrm{Mb}}=$ Amount $_{\mathrm{Me}} \times$ Wood price $\times$ Wood calorific values of fuel wood

Wastes can be treated onsite or by a service provider. If waste treatment occurs at the factory, involving electricity for the treatment has to be calculated as shown in Equation (A6). Depending on how factories pay fee to the service provider, cost of solid waste treatment can be calculated by Equations (A8a) or (A8b) based on amount and time, respectively. In Equation (A8a), solid waste 
amount from processing can be from the difference between inputs and outputs. Equation (A8b) is used when the fee is a flat rate per year.

$$
\begin{gathered}
\text { Solid waste } \operatorname{cost}_{\mathrm{Ms}}=\text { Amount }_{\mathrm{Mws}} \times \text { Cost rate }_{\mathrm{Mws}} \\
\text { Solid waste cost } \mathrm{Ms}_{\mathrm{Ms}}=\mathrm{T}_{\mathrm{B}} \times \text { Yearly fee } \mathrm{Ms}_{\mathrm{Ms}} / \mathrm{T}_{\mathrm{F}}
\end{gathered}
$$

where $\mathrm{T}_{\mathrm{F}}$ refers to factory working hours per year.

Costs of factory rent, as well as sample check and delivery are calculated by Equations (A9) to (A11).

$$
\begin{gathered}
\text { Rent }_{\mathrm{Mr}}=\mathrm{T}_{\mathrm{B}} \times \text { Monthly fee } \mathrm{Mr}_{\mathrm{Mr}} / \mathrm{T}_{\mathrm{F}} / 12 \\
\text { Sample check fee } \mathrm{Msf}=\mathrm{Lab} \text { test fee } \mathrm{Msf}_{\mathrm{Ms}} / \mathrm{N}_{\mathrm{B}}
\end{gathered}
$$

where $N_{B}$ is the number of production batch which is used for allocating sample check costs into the number of batches produced with the tested materials or components and the checked product sample.

Costs relating to sustainability assurance activities performed by manufacturers are calculated by Equations (A12)-(A14) for acquiring and implement sustainability certificates and for employer social security contribution.

$$
\begin{aligned}
& \text { Certificate fee } \mathrm{Mcf}=\left(\text { Certificate fee }_{\mathrm{SMcf}}+\text { Auditing fee } \mathrm{Mcf}_{\mathrm{Cf}}\right) \times \mathrm{T}_{\mathrm{B}} /\left(\text { Number of certified year } \times \mathrm{T}_{\mathrm{F}}\right) \\
& \text { Employee training cost }=\text { Learning time } \mathrm{Mcm}, \mathrm{Mco} \times \text { Hourly wage } \times \mathrm{T}_{\mathrm{B}} /\left(\text { Total certified year } \times \mathrm{T}_{\mathrm{F}}\right)
\end{aligned}
$$

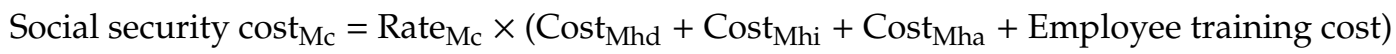

For the other overhead costs, users may use actual costs from factories or estimate them by multiplying a percentage with the summation of Equations (A1)-(A14). After that, profit margins of manufacturers at $d, c$, and $b$ stages can be estimated by multiplying a percentage with the summation of Equations (A1)-(A14) and the other overheads cost. The percentages for the other overheads and profit margin depend on industries. Finally, the summation of Equations (A1)-(A14), the other overheads cost, and the profit margin is EXW price of materials, components, or products to the next supply chain tier/stage. The summation of EXW price and logistics costs to the location of the next stage is landed cost of materials, components, or products.

Manufacturing $\mathrm{CO}_{2} \mathrm{e}$ is derived from the summation of $\mathrm{CO}_{2}$ e from activities relating to factors shown in Figure 2 at each $d, c$, and b manufacturing locations. Each activity $\mathrm{CO}_{2} \mathrm{e}$ is calculated by Equation (A15).

$$
\mathrm{CO}_{2} \mathrm{e}=\left(\left(\mathrm{EF}_{\mathrm{CO} 2} \times \mathrm{GWP}_{\mathrm{CO} 2}\right)+\left(\mathrm{EF}_{\mathrm{CH} 4} \times \mathrm{GWP}_{\mathrm{CH} 4}\right)+\left(\mathrm{EF}_{\mathrm{N} 2 \mathrm{O}} \times \mathrm{GWP}_{\mathrm{N} 2 \mathrm{O}}\right)\right) \times \text { Manufacturing rates }
$$

where Manufacturing rates, which are defined in Step 3 of the proposed approach, are amounts of consumed electricity for processing (Mep), waste treatment (Mew), and light/air/overheads (Meo), of heat generated onsite by biomass (Me), of solid wastes to landfill (Mws), and of delivered samples (Msd) and distance from factories to the headquarter and laboratory for quality and chemicals checking. Each EF collected in Step 5 is aligned to each factor of manufacturing activity rates. These $\mathrm{CO}_{2} \mathrm{e}$ computations can be applied for computing $\mathrm{CO}_{2} \mathrm{e}$ from the recycling process.

\section{Appendix B.2. Logistics Cost and CO2e Computations}

Logistics cost is calculated by summing international transportation, freight insurance, domestic transportation to/from ports in case of ship, import duties, and port fees shown in Equation (A16).

$$
\operatorname{Cost}_{\mathrm{L}}=\operatorname{Cost}(\mathrm{Lm}, \mathrm{Lw} \text { or Ls, } \mathrm{Ld})+\operatorname{Cost}_{\mathrm{Li}}+\operatorname{Cost}_{\mathrm{Lt}}+\operatorname{Cost}_{\mathrm{Lo}}+\operatorname{Cost}_{\mathrm{Ll}}
$$


The transportation and insurance costs can be obtained from logistics providers or from the multiplication of size and/or weight of transported goods and distance data from Step 3 with transportation cost rates from Step 4 . The import duties can be calculated by multiplying import duty rates from Step 4 with the summation of EXW price of transported goods, domestic and international transportation costs, and insurance cost.

Logistics $\mathrm{CO}_{2} \mathrm{e}$ can be calculated by multiplying distance data from Step 3 with EFs of transportation mode from Step 5 and use GWP for $\mathrm{CO}_{2} \mathrm{e}$ conversion. Logistic $\mathrm{CO}_{2} \mathrm{e}$ for each transportation route from $\mathrm{d}$ to $\mathrm{c}, \mathrm{c}$ to $\mathrm{b}$, and $\mathrm{b}$ to $\mathrm{a}$ are calculated by Equation (A17).

$\mathrm{CO}_{2} \mathrm{e}_{\mathrm{L}}=\left(\left(\mathrm{EF}_{\mathrm{CO} 2} \times \mathrm{GWP}_{\mathrm{CO} 2}\right)+\left(\mathrm{EF}_{\mathrm{CH} 4} \times \mathrm{GWP}_{\mathrm{CH} 4}\right)+\left(\mathrm{EF}_{\mathrm{N} 2 \mathrm{O}} \times \mathrm{GWP}_{\mathrm{N} 2 \mathrm{O}}\right)\right) \times$ Weight $\times$ Distance

$\mathrm{CO}_{2} \mathrm{e}_{\mathrm{L}}$ includes both domestic and international transportations and their EFs depend on transportation mode. Cost and $\mathrm{CO}_{2} \mathrm{e}$ from reverse logistics to recycling locations are also calculated by Equations (A16) and (A17).

\section{Appendix B.3. Firm's Sustainability Assurance Activity Cost and CO2e Computations}

Firm's sustainability-assurance costs relate transportation, hotel, and manager costs to visit a factory and interests on capital for firm's cash flow ensuring business sustainability. They are calculated according to Equations (A18)-(A22). Costs relating to a factory visit are allocated into the number of production batches before the next visit of an employee from headquarter for new styles and products as well as for solving problems.

$$
\begin{gathered}
\operatorname{Cost}_{\mathrm{F}}=\operatorname{Cost}_{\mathrm{Fh}}+\operatorname{Cost}_{\mathrm{Ft}}+\operatorname{Cost}_{\mathrm{Fm}}+\operatorname{Cost}_{\mathrm{Fi}} \\
\operatorname{Cost}_{\mathrm{Fh}}=\text { Hotel night rate } \times \text { Number of travelling nights for a factory visit } / \mathrm{N}_{\mathrm{B}} \\
\operatorname{Cost}_{\mathrm{Ft}}=(\text { Domestic transportation costs }+ \text { International transportation cost }) / \mathrm{N}_{\mathrm{B}} \\
\operatorname{Cost}_{\mathrm{Fm}}=\text { Hourly wage } \times \text { Number of travelling hours } / \mathrm{N}_{\mathrm{B}} \\
\operatorname{Cost}_{\mathrm{Fi}}=\text { Yearly rate } \mathrm{Fi}_{\mathrm{Fi}} / 365 \times(\text { Total cost } \\
\mathrm{M}
\end{gathered}
$$

where LT is total lead time from manufacturing, logistics, and firm activities.

Sustainability Assurance $\mathrm{CO}_{2}$ e relates only the employee transportation including both domestic and international transportations of passengers. Their EFs depend on transportation mode. Passenger transportation $\mathrm{CO}_{2} \mathrm{e}$ is calculated according to Equation (A23).

$$
\mathrm{CO} 2 \mathrm{e}_{\mathrm{F}}=\left(\left(\mathrm{EF}_{\mathrm{CO} 2} \times \mathrm{GWP}_{\mathrm{CO} 2}\right)+\left(\mathrm{EF}_{\mathrm{CH} 4} \times \mathrm{GWP}_{\mathrm{CH} 4}\right)+\left(\mathrm{EF}_{\mathrm{N} 2 \mathrm{O}} \times \mathrm{GWP}_{\mathrm{N} 2 \mathrm{O}}\right)\right) \times \text { distance }
$$




\section{Appendix C. Analysis Results from the Viscose T-Shirt Application}

Appendix C.1. Cost and Carbon Dioxide Equivalent (CO2e) Ranking Results

Table A23. The 16 lowest cost and $\mathrm{CO}_{2} \mathrm{e}$ supply chains for the European market and their cost and CO2e values for $1800 \mathrm{t}$-shirt manufacturing.

\begin{tabular}{ccccc}
\hline Rank & $\begin{array}{c}\text { Low-Cost Supply } \\
\text { Chain }\end{array}$ & $\boldsymbol{\epsilon}$ & $\begin{array}{c}\text { Low-CO } \mathbf{e} \text { Supply } \\
\text { Chain }\end{array}$ & $\mathbf{k g C O}_{\mathbf{2}} \mathbf{e}$ \\
\hline 1 & US-EG-EG & 7768 & AT-AT-AT & 6122 \\
2 & ID-EG-EG & 7777 & AT-DE-DE & 6190 \\
3 & US-TN-TN & 7921 & AT-DE-AT & 6198 \\
4 & CN(N)-EG-EG & 7973 & AT-AT-DE & 6248 \\
5 & TH-EG-EG & 8051 & AT-DE-GB & 6393 \\
6 & CN(N)-TN-TN & 8074 & AT-IT-AT & 6392 \\
7 & ID-TN-TN & 8134 & AT-AT-IT & 6406 \\
8 & AT-EG-EG & 8215 & AT-DE-IT & 6431 \\
9 & GB-EG-EG & 8301 & AT-AT-LT & 6438 \\
10 & TH-TN-TN & 8408 & AT-IT-DE & 6460 \\
11 & ID-TR-TR & 8520 & AT-DE-LT & 6462 \\
12 & US-TR-TR & 8521 & AT-AT-GB & 6483 \\
13 & AT-TN-TN & 8572 & AT-GB-DE & 6503 \\
14 & US-PL-PL & 8634 & AT-LT-AT & 6511 \\
15 & GB-TN-TN & 8658 & AT-GB-AT & 6543 \\
16 & AT-PL-PL & 8685 & AT-IT-IT & 6548 \\
\hline
\end{tabular}

Remarks: Alternative names refer to locations of fiber, fabric, and garment manufacturing; and AT = Austria, $\mathrm{CN}$ (N) = China (Nanjing), ID = Indonesia, GB = Great Britain, US = the United States, TH = Thailand, DE = Germany, $\mathrm{PL}=$ Poland, $\mathrm{IT}=$ Italy, $\mathrm{LT}=$ Lithuania, $\mathrm{TN}=$ Tunisia, $\mathrm{EG}=$ Egypt, $\mathrm{TR}=$ Turkey .

Appendix C.2. Important Cost and CO2e Factors by Stacked Column Charts

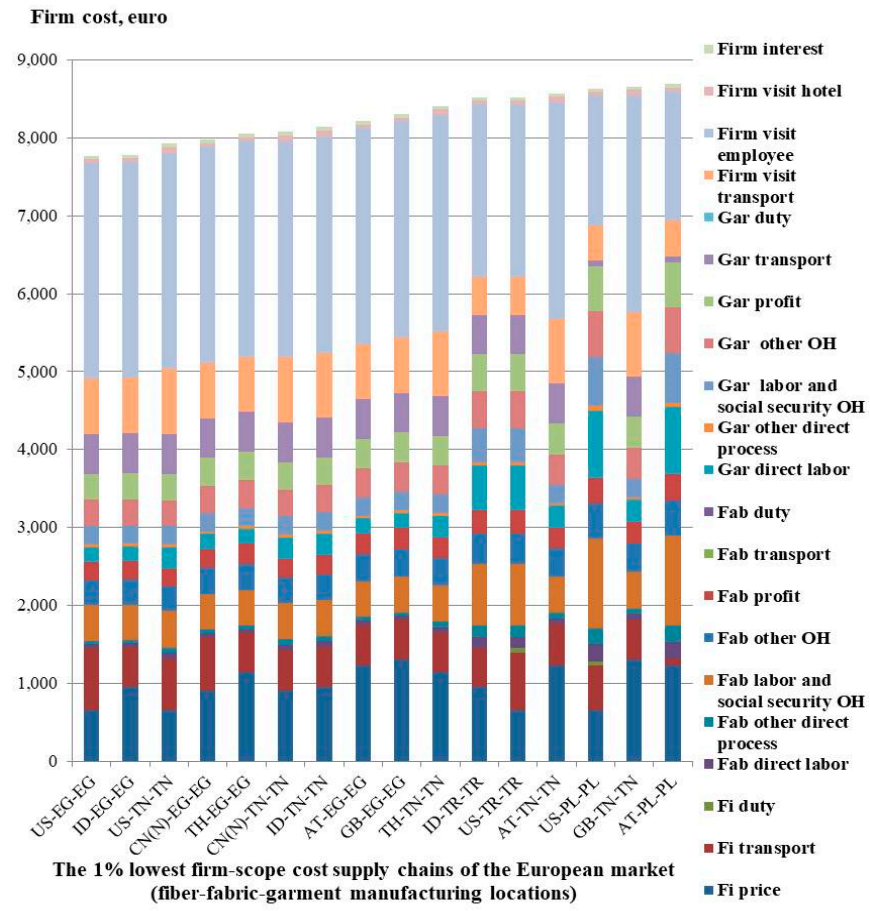

Figure A1. Breakdown costs of the 16 lowest cost supply chains for one $1800 \mathrm{t}$-shirt batch. Remarks: Fi, $\mathrm{Fab}$, and Gar refer to fibers, fabrics, and garments; $\mathrm{OH}$ is overheads; and $\mathrm{AT}=$ Austria, $\mathrm{CN}(\mathrm{N})=\mathrm{China}$ (Nanjing), ID = Indonesia, GB = Great Britain, US = the United States, TH = Thailand, DE = Germany, $\mathrm{PL}=$ Poland, $\mathrm{TN}=$ Tunisia, $\mathrm{EG}=$ Egypt, $\mathrm{TR}=$ Turkey . 


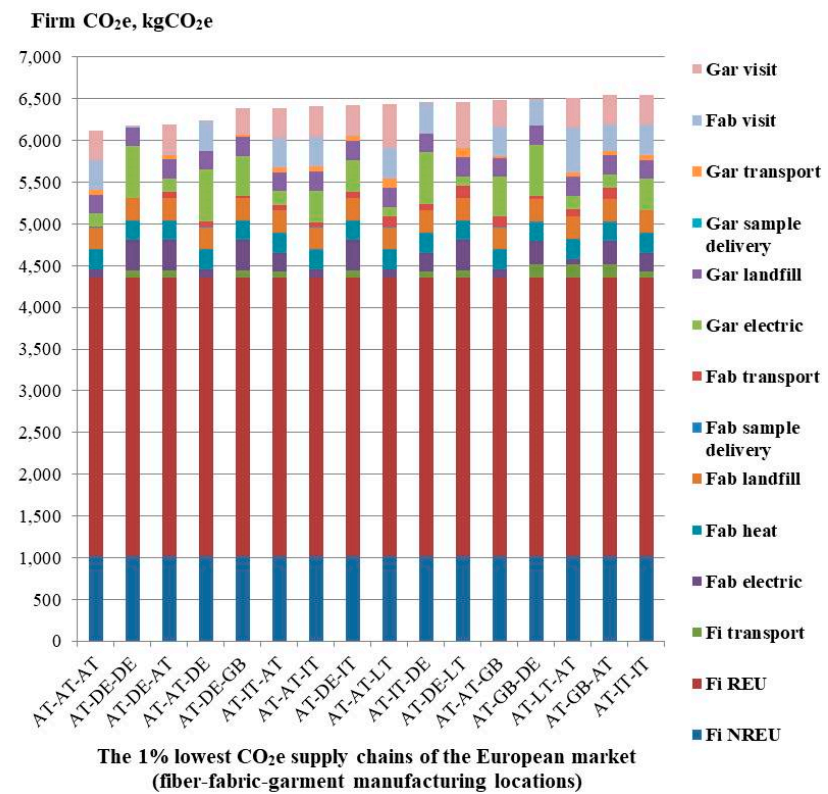

Figure A2. Breakdown $\mathrm{CO}_{2} \mathrm{e}$ of the 16 lowest $\mathrm{CO}_{2} \mathrm{e}$ supply chains for one $1800 \mathrm{t}$-shirt batch. Remarks: $\mathrm{Fi}$, Fab, and Gar refer to fibers, fabrics, and garments; NREU and REU are non-renewable and renewable energy use; and AT = Austria, GB = Great Britain, DE = Germany, IT = Italy, LT = Lithuania.

Appendix C.3. Optimized Cost and CO2e Pareto Supply Chains by a Scatter Plot

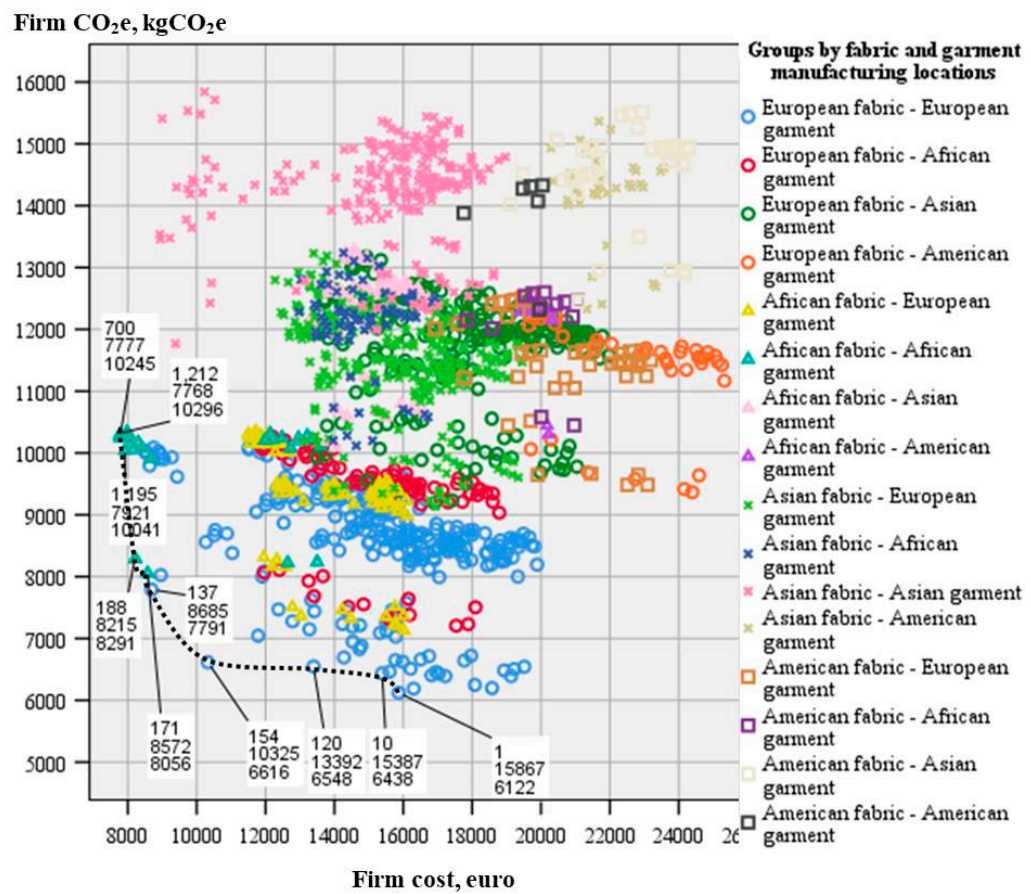

Figure A3. Optimized low cost and $\mathrm{CO}_{2} \mathrm{e}$ supply chains on the Pareto frontier of the categorical scatter plotting between the firm-scope costs and $\mathrm{CO}_{2} \mathrm{e}$ of all 1536 possible supply chains for a 1800-t-shirt batch. Remarks: Each supply chain on the Pareto frontier shows index number to fiber, fabric, and garment manufacturing locations, as well as its cost and $\mathrm{CO}_{2} \mathrm{e} ; 1=$ AT-AT-AT, $10=$ AT-AT-LT, $120=$ AT-IT-IT, $154=$ AT-LT-LT, 137 = AT-PL-PL, $171=$ AT-TN-TN, $188=$ AT-EG-EG, $1195=$ US-TN-TN, $700=$ ID-EG-EG, 1212 = US-EG-EG; and AT = Austria, ID = Indonesia, US = the United States, IT = Italy, PL = Poland, $\mathrm{LT}=$ Lithuania, $\mathrm{TN}=$ Tunisia, $\mathrm{EG}=$ Egypt. 


\section{References}

1. Tse, Y.K.; Tan, K.H. Managing product quality risk and visibility in multi-layer supply chain. Int. J. Prod. Econ. 2012, 139, 49-57. [CrossRef]

2. Elkington, J. Triple bottom line. In Berkshire Encyclopedia of Sustainability; Laszlo, C., Christensen, K., Fogel, D., Wagner, G., Whitehouse, P., Eds.; Berkshire: Great Barrington, MA, USA, 2010; Volume 2, pp. 464-467.

3. Tachizawa, E.M.; Wong, C.Y. Towards a theory of multi-tier sustainable supply chains: A systematic literature review. Int. J. Supply Chain Manag. 2014, 19, 643-663. [CrossRef]

4. Dou, Y.; Zhu, Q.; Sarkis, J. Green multi-tier supply chain management: An enabler investigation. J. Purch. Supply Manag. 2018, 24, 95-107. [CrossRef]

5. Mena, C.; Humphries, A.; Choi, T.Y. Toward a theory of multi-tier supply chain management. J. Supply Chain Manag. 2013, 49, 58-77. [CrossRef]

6. Sauer, P.C.; Seuring, S. A three-dimensional framework for multi-tier sustainable supply chain management. Int. J. Supply Chain Manag. 2018, 23, 560-572. [CrossRef]

7. Wilhelm, M.M.; Blome, C.; Bhakoo, V.; Paulraj, A. Sustainability in multi-tier supply chains: Understanding the double agency role of the first-tier supplier. J. Oper. Manag. 2016, 41, 42-60. [CrossRef]

8. Wilhelm, M.; Blome, C.; Wieck, E.; Xiao, C.Y. Implementing sustainability in multi-tier supply chains: Strategies and contingencies in managing sub-suppliers. Int. J. Prod. Econ. 2016, 182, 196-212. [CrossRef]

9. Sirilertsuwan, P.; Hjelmgren, D.; Ekwall, D. Exploring current enablers and barriers for sustainable proximity manufacturing. J. Fash. Mark. Manag 2019, 23, 551-571. [CrossRef]

10. Perez Loaiza, R.E.; Olivares-Benitez, E.; Miranda Gonzalez, P.A.; Guerrero Campanur, A.; Martinez Flores, J.L. Supply chain network design with efficiency, location, and inventory policy using a multiobjective evolutionary algorithm. Int. Trans. Oper. Res. 2017, 24, 251-275. [CrossRef]

11. Xu, W.; Liu, L.; Zhang, Q.; Wang, X. A multi-object decision-making method for location model of manufacturing industry under uncertain environment. J. Interdiscip. Math. 2017, 20, 1019-1028. [CrossRef]

12. Hammami, R.; Frein, Y.; Bahli, B. Supply chain design to guarantee quoted lead time and inventory replenishment: Model and insights. Int. J. Prod. Res. 2017, 55, 3431-3450. [CrossRef]

13. Teimoury, E.; Amiri, S.O.H.; Ketabchi, F. Incorporating vehicle routing, location and supplier selection problems for reducing pollutants emission. Ind. Eng. Manag. Syst. 2017, 16, 574-589. [CrossRef]

14. Srinivasan, S.; Khan, S.H. Multi-stage manufacturing/re-manufacturing facility location and allocation model under uncertain demand and return. Int. J. Adv. Manuf. Technol. 2018, 94, 2847-2860. [CrossRef]

15. Zhen, L.; Sun, Q.; Wang, K.; Zhang, X. Facility location and scale optimisation in closed-loop supply chain. Int. J. Prod. Res. 2019, 57, 7567-7585. [CrossRef]

16. Lara, C.L.; Bernal, D.E.; Li, C.; Grossmann, I.E. Global optimization algorithm for multi-period design and planning of centralized and distributed manufacturing networks. Comput. Chem. Eng. 2019, 127, $295-310$. [CrossRef]

17. Mishra, S.; Singh, S.P. An environmentally sustainable manufacturing network model under an international ecosystem. Clean Technol. Environ. Policy 2019, 21, 1237-1257. [CrossRef]

18. Alizadeh, M.; Ma, J.; Mahdavi-Amiri, N.; Marufuzzaman, M.; Jaradat, R. A stochastic programming model for a capacitated location-allocation problem with heterogeneous demands. Comput. Ind. Eng. 2019, 137, 106055. [CrossRef]

19. Brush, T.H.; Marutan, C.A.; Karnani, A. The plant location decision in multinational manufacturing firms: An empirical analysis of international business and manufacturing strategy perspectives. Prod. Oper. Manag. J. 1999, 8, 109-132. [CrossRef]

20. Chaabane, A.; Ramudhin, A.; Paquet, M. Design of sustainable supply chains under the emission trading scheme. Int. J. Prod. Econ. 2010, 135, 37-49. [CrossRef]

21. Kuo, T.-C.; Tseng, M.-L.; Chen, H.-M.; Chen, P.-S.; Chang, P.-C. Design and analysis of supply chain networks with low carbon emissions. Comput. Econ. 2018, 52, 1353-1374. [CrossRef]

22. Kuo, C.T.; Lee, Y. Using Pareto Optimization to Support Supply Chain Network Design within Environmental Footprint Impact Assessment. Sustainability 2019, 11, 452. [CrossRef]

23. Nouira, I.; Hammami, R.; Frein, Y.; Temponi, C. Design of forward supply chains: Impact of a carbon emissions-sensitive demand. Int. J. Prod. Econ. 2016, 173, 80-98. [CrossRef] 
24. Ramudhin, A.; Chaabane, A.; Paquet, M. Carbon market sensitive sustainable supply chain network design. Int. J. Manag. Sci. Eng. Manag. 2010, 5, 30-38. [CrossRef]

25. Weber, A. Alfred Weber's Theory of the Location of Industries; Friedrich, C.J., Ed.; The University of Chicago Press: Chicago, IL, USA, 1929.

26. Chen, L.; Olhager, J.; Tang, O. Manufacturing facility location and sustainability: A literature review and research agenda. Int. J. Prod. Econ. 2014, 149, 154-163. [CrossRef]

27. Brandenburg, M.; Govindan, K.; Sarkis, J.; Seuring, S. Quantitative models for sustainable supply chain management: Developments and directions. Eur. J. Oper. Res. 2014, 233, 299-312. [CrossRef]

28. Dou, Y.; Sarkis, J. A joint location and outsourcing sustainability analysis for a strategic offshoring decision. Int. J. Prod. Res. 2010, 48, 567-592. [CrossRef]

29. Ritchie, W.J. Managerial Cognitions and Objective Measures of Organization Performance: What Shapes Convergence? Ph.D. Thesis, The Florida State University, Tallahassee, FL, USA, 2001.

30. Daniels, J.; Werner, P.; Bahill, A.T. Quantitative methods for tradeoff analysis. Syst. Eng. 2001, 4, $190-212$. [CrossRef]

31. Lima-Junior, F.R.; Carpinetti, L.C.R. Quantitative models for supply chain performance evaluation: A literature review. Comput. Ind. Eng. 2017, 113, 333-346. [CrossRef]

32. Sirilertsuwan, P.; Ekwall, D.; Hjelmgren, D. Proximity manufacturing for enhancing clothing supply chain sustainability. Int. J. Logist. Manag. 2018, 29, 1346-1378. [CrossRef]

33. Seltman, H.J. Exploratory data analysis and learning SPSS: Data and EDA. In Experimental Design and Analysis; Carnegie Mellon University Statistics and Data Science: Pittsburgh, PA, USA, 2018; pp. 61-193.

34. Wright, G.; Bradfield, R.; Cairns, G. Does the intuitive logics method-and its recent enhancements-produce "effective" scenarios? Technol. Forecast. Soc. Chang. 2013, 80, 631-642. [CrossRef]

35. Lotov, A.V. Interactive Decision Maps Approximation and Visualization of Pareto Frontier, 1st ed.; Springer US: New York, NY, USA, 2004.

36. Triantaphyllou, E.; Sánchez, A. A sensitivity analysis approach for some deterministic multi-criteria decision-making methods*. Decis. Sci. 1997, 28, 151-194. [CrossRef]

37. Yvonne Feilzer, M. Doing mixed methods research pragmatically: Implications for the rediscovery of pragmatism as a research paradigm. J. Mix Methods Res. 2009, 4, 6-16. [CrossRef]

38. Tate, W.L.; Ellram, L.M.; Schoenherr, T.; Petersen, K.J. Global competitive conditions driving the manufacturing location decision. Bus. Horiz. 2014, 57, 381-390. [CrossRef]

39. Clark, H.; Anderson, A.A. Theories of change and logic models: Telling them apart. In Proceedings of the American Evaluation Association Conference, Atlanta, GA, USA, 3-6 November 2004.

40. Millar, A.; Simeone, R.S.; Carnevale, J.T. Logic models: A systems tool for performance management. Eval. Program. Plann. 2001, 24, 73-81. [CrossRef]

41. Askarany, D.; Yazdifar, H.; Askary, S. Supply chain management, activity-based costing and organisational factors. Int. J. Prod. Econ. 2010, 127, 238-248. [CrossRef]

42. Oliva, R. Intervention as a research strategy. J. Oper. Manag. 2019, 65, 710-724. [CrossRef]

43. Seuring, S.; Müller, M. From a literature review to a conceptual framework for sustainable supply chain management. J. Clean. Prod. 2008, 16, 1699-1710. [CrossRef]

44. Greenhouse Gas Protocol. Calculation Tools. Available online: https://ghgprotocol.org/calculation-tools (accessed on 25 December 2019).

45. The Intergovernmental Panel on Climate Change (IPCC). EFDB Emission Factor Database. Available online: https://www.ipcc-nggip.iges.or.jp/EFDB/main.php (accessed on 18 July 2019).

46. Ferdows, K. Making the most of foreign factories. Harv. Bus. Rev. 1997, 75, 73-91.

47. Statista. Apparel and Clothing Market Europe-Statistics and Facts; Sabanoglu, T., Ed.; Available online: https://www.statista.com/topics/3423/clothing-and-apparel-market-in-europe/ (accessed on 1 June 2019).

48. Angelstam, M.; Artman, A.; Hanström, J.; Rodríguez, D.M.; Uskali, D. Comparative LCA: Viscose vs Cotton T-shirts. In AG2800 Life Cycle Assessment; KTH Royal Institute of Technology: Stockholm, Sweden, 2016.

49. Shen, L.; Patel, M.K. Life cycle assessment of man-made cellulose fibres. Lenzing. Ber. 2010, 88, 1-59.

50. Overview of a Knit-Dyeing Factory with Necessary Production Formulas. Available online: http://www.engi neeringresearch.org/index.php/GJRE/article/view/1013 (accessed on 20 April 2019). 
51. Phakphonhamin, V.; Chudokmai, M. Optimizing the performance of the LECTRA automatic fabric cutting machine. In Proceedings of the 5th International Conference on Business and Industrial Research (ICBIR), Bangkok, Thailand, 17-18 May 2018; pp. 282-287.

52. Rahman, H.; Roy, P.K.; Karim, R.; Biswas, P.K. Effective way to estimate the standard minute value (SMV) of a t-shirt by work study. Eur. Sci. Ed. 2014, 10, 30.

53. Yin, H.; Qiu, P.; Qian, Y.; Kong, Z.; Zheng, X.; Tamg, Z.; Guo, H. Textile wastewater treatment for water reuse: A case study. Processes 2019, 7, 34. [CrossRef]

54. Brander, M.; Sood, A.; Wylie, C.; Haughton, A.; Lovell, J. Technical Paper: Electricity-Specific Emission Factors for Grid Electricity. Ecometrica. Available online: https://ecometrica.com/assets/Electricity-specific-e mission-factors-for-grid-electricity.pdf (accessed on 29 April 2019).

55. FlyGreen. Available online: https://flygrn.com/ (accessed on 25 December 2019).

56. European Environment Agency. Total Greenhouse Gas Emission Trends and Projections in Europe. Available online: https://www.eea.europa.eu/data-and-maps/indicators/greenhouse-gas-emission-trends-6/assess ment-3\#: \{\}:text=In\%202017\%2C\%20the\%20EU \T1 \textquoterights $\% 20$ greenhouse,2\%20\%25\%20from\%20 2017\%20to\%202018 (accessed on 12 January 2020).

57. Fezzigna, P.; Borghesi, S.; Caro, D. Revising emission responsibilities through consumption-based accounting: A European and Post-Brexit perspective. Sustainability (Baselswitzerland) 2019, 11, 488. [CrossRef]

58. Textile School. Energy Consumption for Spinning Machines and Compressed Air. 2018. Available online: http s://www.textileschool.com/245/energy-consumption-for-spinning-machines-and-compressed-air/ (accessed on 15 April 2019).

59. Alibaba.com. Product Search: Thread Spinning Machine. Available online: https://www.alibaba.com/tr ade/search?fsb=y\&IndexArea=product_en\&CatId=\&SearchText=thread+spinning +machine (accessed on 15 April 2019).

60. Seair Exim Solution. Available online: https://www.seair.co.in/import-data-hs-code-5504.aspx (accessed on 17 April 2019).

61. Eurostat Statistics Explained. Electricity Prices, First Semester of 2016-2018. Available online: https://ec. europa.eu/eurostat/statistics-explained/index.php?title=File:Electricity_prices,_First_semester_of_2016-2018 _(EUR_per_kWh).png (accessed on 18 April 2019).

62. Alibaba.com. Product Search: Wood Chip. Available online: https://www.alibaba.com/trade/search?fsb=y\&I ndexArea=product_en\&CatId=\&SearchText=wood+chip\&viewtype=\&tab= $($ accessed on 20 April 2019).

63. CEIC. China Electricity Price. Available online: www.ceicdata.com/en/china/electricity-price?page=3 (accessed on 18 April 2019).

64. Alibaba.com. Product Search: Used t-shirt. Available online: https://www.alibaba.com/trade/search?fsb=y \&IndexArea=product_en\&CatId=\&SearchText=used+t-shirt\&viewtype=\&tab= $($ accessed on 26 December 2019).

65. Netralnews.com. Energy Ministry: Electricity Tariffs in Indonesia Most Stable in Southeast Asia. 2018. Available online: www.en.netralnews.com/news/business/read/23765/energy.ministry.electricity.tariffs.in.in donesia.most.stable.in.southeast.asia (accessed on 18 April 2019).

66. Rocky Mountain Power. Available online: www.rockymountainpower.net/about/rar/ipc.html (accessed on 18 April 2019).

67. TRADING ECONOMICS. Germany Bank Lending Rate. Available online: https://tradingeconomics.com/ger many/bank-lending-rate (accessed on 26 December 2019).

68. Energypedia. Tunisia Energy Situation. Available online: https://energypedia.info/wiki/Tunisia_Energy_Sit uation (accessed on 18 April 2019).

69. Mada. Government Raises Electricity Tariffs for Industrial Producers by up to 43\%. 2018. Available online: https://madamasr.com/en/2018/06/13/news/u/government-raises-electricity-tariffs-for-industrialproducers-by-up-to-43/ (accessed on 18 April 2019).

70. Ukrainian Biofuel Portal. Wood Pellets for Sale from Egypt. Available online: http://pellets-wood.com/woo d-pellets-for-sale-from-egypt-o14715.htmlv (accessed on 20 April 2019).

71. The Daily Star. Power Tariff to Rise from December. 2017. Available online: https://www.thedailystar.net/fro ntpage/power-tariff-rise-dec-1495777 (accessed on 18 April 2019). 
72. Reuters. India Power Tariffs Could Rise 62-93 paise/kWh -power Minister. 2018. Available online: www.reuters.com/article/india-pollution-power/india-power-tariffs-could-rise-62-93-paise-kwhpower-minister-idUSL4N1OX1PP (accessed on 18 April 2019).

73. IndiaMART. Product Search: Wood Chip. Available online: https://www.indiamart.com/proddetail/woodenchips-20163248173.html (accessed on 20 April 2019).

74. OECD iLibrary. Environment at a Glance 2015 (Table 1.6. Water Prices in Selected Major Cities, 2013). Available online: https://read.oecd-ilibrary.org/environment/environment-at-a-glance-2015_9789264235199en\#page39 (accessed on 19 April 2019).

75. Realestate.com.au. Search: Industrial/Warehouse for Rent in Austria and Indonesia. Available online: www.realestate.com.au/international/at/rent/industrial-warehouse/p4/ (accessed on 22 April 2019).

76. Rutkowski, R. The Economics of H2O: Water Price Reforms in China. The Peterson Institute for International Economics (PIIE) 2014. Available online: https://piie.com/blogs/china-economic-watch/economics-h2o-wate r-price-reforms-china (accessed on 19 April 2019).

77. DBS Bank. Available online: https://www.dbs.com/aics/pdfController.page\%3Fpdfpath\%3D/content/article/p df/000000_sectors/201707/RE_CN_Warehouse_2017-05.pdf+\&cd=1\&hl=en\&ct=clnk\&gl=fr\&client=safari (accessed on 22 April 2019).

78. Japan International Cooperation Agency; PricewaterhouseCoopers Co., Ltd.; PADECO Co., Ltd.; Yokohama Water Co., Ltd. Final Report: Study of the Tariff Pricing and the Impact of Cross-Subsidy for Water Supply and Sewerage in Bangladesh. 2011. Available online: http://open_jicareport.jica.go.jp/pdf/12028130.pdf (accessed on 19 April 2019).

79. Realla. Search: Industrial Rent in Grimsby. Available online: https://realla.co/rent/industrial/Grimsby (accessed on 22 April 2019).

80. LoopNet. Search: Industrial Lease in Alabama. Available online: https://www.loopnet.com (accessed on 22 April 2019).

81. Thailand Borad of Investment. Available online: www.boi.go.th/newboi/upload/content/Cost $\% 20$ of $\% 20 \mathrm{doin}$ g\%202018-date_7\%20Mar\%202018_5aa7c1f8ae9b4.pdf (accessed on 19 April 2019).

82. DDproperty. Search: Commercial Rent in Prachinburi. Available online: https://www.ddproperty.com (accessed on 22 April 2019).

83. International Water Association (IWA). International Statistics for Water Services 2012. 2016. Available online: https://iwa-network.org/publications/international-statistics-for-water-services-2012/ (accessed on 19 April 2019).

84. Arkadia. Search Commercial for Rent in Germany. Available online: https://en.arkadia.com/for-rent/commer cial/germany-g276/ (accessed on 22 April 2019).

85. Engel \& Völkers. Industry or Production Properties and Warehouses to Rent in Italy. Available online: www.engelvoelkers.com/en-it/properties/ (accessed on 22 April 2019).

86. Cushman \& Wakefield. Available online: http://www.poland-industrial.com/en/warehouses (accessed on 22 April 2019).

87. Invest Lithuania. Available online: https:/investlithuania.com/investor-guide/running-your-business/ (accessed on 23 April 2019).

88. Foreign Investment Promotion Agency (FIPA) Tunisia. Available online: http://www.investintunisia.tn/En/te lecharger_publication.php?code_doc=178\&langue_doc=en (accessed on 20 April 2019).

89. Home in Tunisia. Available online: http://www.homeintunisia.com/en/rentals/industriel-permises (accessed on 23 April 2019).

90. The IBNET tariff database. Greater Cairo Water Company(Egypt). Available online: https://tariffs.ib-net.org/ View Tariff?tariffld=2254\&countryId=141 (accessed on 20 April 2019).

91. Healy Consultants Group PLC. Available online: https://www.healyconsultants.com/egypt-company-registr ation/free-zones/ (accessed on 23 April 2019).

92. Rota Capital Financial Concultancy. Guide for Investors in Turkey. Available online: http://rotacapital.com/ invest\%20in\%20turkey\%20guide.pdf (accessed on 20 April 2019).

93. Düzener Emlak. Available online: http://duzeneremlak.com (accessed on 23 April 2019).

94. The Daily Start. Utility Tariffs Set to Rise. 2018. Available online: www.thedailystar.net/frontpage/utility-tar iffs-water-gas-and-electricity-price-increase-1574113 (accessed on 20 April 2019). 
95. Bdnews24 Classifieds. Factory rent in Bangladesh. Available online: https://bdnews24.com/classifieds/com mercial-property/factory-rent-in-bangladesh.html (accessed on 23 April 2019).

96. Jain, B. Maharashtra Govt Increases Water Tariff for Industries Using It as Raw Material. 2018. The Times of India. Available online: https://timesofindia.indiatimes.com/city/mumbai/maharashtra-govt-increases-wate r-tariff-for-industries-using-it-as-raw-material/articleshow/62573525.cms (accessed on 20 April 2019).

97. RealEstateIndia.com. Available online: https://www.realestateindia.com/property-detail/factory-industrial-b uilding-for-rent-in-bhatar-road-surat-5000-sq-ft-768232.htm (accessed on 23 April 2019).

98. Kaza, S.; Yao, L.; Bhada-Tata, P.; Van Woerden, F. What a Waste 2.0: A Global Snapshot of Solid Waste Management to 2050; Urban Development; World Bank: Washington, DC, USA, 2018; Available online: https://openknowledge.worldbank.org/handle/10986/30317 (accessed on 21 April 2019).

99. WageIndicator Foundation. Available online: https://wageindicator.org/salary/wages-in-context (accessed on 20 December 2019).

100. Minimum-Wage.org. Search: Thailand and Tunisia. Available online: https://www.minimum-wage.org/inter national (accessed on 20 December 2019).

101. WageIndicator Foundation. Wages in Context in the Garment Industry in Asia: THE CASE OF CHINA. Available online: https://wageindicator.org/documents/publicationslist/publications-2016/wages-in-contextin-the-garment-industry-in-asia-the-case-of-china (accessed on 20 December 2019).

102. Trading Economics. Thailand Average Monthly Wages in Manufacturing. Available online: https://tradinge conomics.com/thailand/wages-in-manufacturing (accessed on 20 December 2019).

103. Numbeo. Cost of Living in Monastir. Available online: www.numbeo.com/cost-of-living/in/Monastir-Tunisia (accessed on 20 December 2019).

104. KPMG. Employer Social Security Tax Rates. Available online: https://home.kpmg/xx/en/home/service s/tax/tax-tools-and-resources/tax-rates-online/social-security-employer-tax-rates-table.html (accessed on 22 December 2019).

105. Average Salary Survey. Salaries by Countries. Available online: https://www.averagesalarysurvey.com/ (accessed on 21 December 2019).

106. CQS (Certified Quality System). Certification \& Audit Fees. Available online: https://www.cqsltd.com/about -cqs/fees.aspx (accessed on 22 December 2019).

107. CE Marking Handmade Toys Collective. Lab Testing. Available online: https://www.cemarking-handmade toys.co.uk/lab-testing/ (accessed on 22 December 2019).

108. Deutsche Post DHL Group. Available online: www.deutschepost.de/de/b/briefe-ins-ausland/warenpost-inte rnational.html\# (accessed on 22 December 2019).

109. Deutsche Post DHL Group. Available online: www.logistics.dhl/fr-en/home/all-products-and-solutions/parc el-and-document-shipping.html (accessed on 22 December 2019).

110. Lufthansa. Available online: https://www.lufthansa.com (accessed on 16 July 2019).

111. Rentalcars.com. Available online: https://www.rentalcars.com/ (accessed on 16 July 2019).

112. Rome2rio. Available online: https://www.rome2rio.com/ (accessed on 16 July 2019).

113. Booking.com. Search: Review score 8+, breakfast, hotel only. Available online: https://www.booking.com/ (accessed on 16 July 2019).

114. SeaRates. Available online: https://www.searates.com/ (accessed on 18 April 2019).

115. World Freight Rates. Available online: https://worldfreightrates.com/ (accessed on 18 April 2019).

116. Freight Insurance Center. Available online: https://freightinsurancecenter.com/ (accessed on 18 April 2019).

117. SimplyDuty. Duty Calculator. Available online: https://www.simplyduty.com/import-calculator/ (accessed on 25 December 2019).

(C) 2020 by the authors. Licensee MDPI, Basel, Switzerland. This article is an open access article distributed under the terms and conditions of the Creative Commons Attribution (CC BY) license (http://creativecommons.org/licenses/by/4.0/). 